\title{
Functional architecture of the pancreatic islets: First responder cells drive the first-phase $\left[\mathrm{Ca}^{2+}\right]$ response
}

\author{
Vira Kravets $^{\mathrm{a}, \mathrm{b}}$, JaeAnn M. Dwulet ${ }^{\mathrm{a}}$, Wolfgang E. Schleicher ${ }^{\mathrm{b}}$, David J. Hodson ${ }^{\mathrm{c}}$, Anna M. \\ Davis, ${ }^{a}$ Robert A. Piscopio ${ }^{b}$, Maura Sticco-Ivins, ${ }^{b}$ Richard K.P. Benninger ${ }^{a, b, 1}$. \\ ${ }^{a}$ Department of Bioengineering, University of Colorado, Anschutz Medical campus, Aurora, \\ CO. USA \\ ${ }^{\mathrm{b}}$ Barbara Davis center for childhood diabetes, University of Colorado, Anschutz Medical \\ campus, Aurora, CO. USA \\ c Institute of Metabolism and Systems Research, University of Birmingham, Birmingham. UK, \\ and Centre for Endocrinology, Diabetes and Metabolism, Birmingham Health Partners, \\ Birmingham, UK
}

${ }^{1}$ To whom correspondence should be addressed:

richard.benninger@cuanschutz.edu Tel: (303) 724-6388. Fax: (303) 724-5800.

1775 Aurora court, M20-4306D, mailstop B140, University of Colorado Anschutz Medical campus, Aurora, CO. 80045.

Short title: First responder cells control islet function

Keywords: Laser ablation; Multicellular Dynamics; Biological Networks; Optical Microscopy; Diabetes; Gap junctions.

Manuscript word count (main text, excluding methods): 5311.

Abstract word count: 294 


\begin{abstract}
Insulin-secreting $\beta$-cells are functionally heterogeneous. Subpopulations of $\beta$-cells can control islet function and the regulation of hormone release, such as driving the second (oscillatory) phase of free-calcium $\left(\left[\mathrm{Ca}^{2+}\right]\right.$ ) following glucose elevation. Whether there exists a subpopulation that drives the first-phase response, critical for effective insulin secretion and disrupted early in diabetes, has not been examined. Here, we examine a 'first responder' cell population, defined by the earliest $\left[\mathrm{Ca}^{2+}\right]$ response during first-phase $\left[\mathrm{Ca}^{2+}\right]$ elevation. We record $\left[\mathrm{Ca}^{2+}\right]$ dynamics in intact mouse islets, via $\beta$-cell specific expression of the $\left[\mathrm{Ca}^{2+}\right]$ indicator GCamP6s. We identify multiple $\beta$-cell subpopulations based on signatures of their $\left[\mathrm{Ca}^{2+}\right]$ dynamics and investigate the role of 'first responder' cells in islet function by means of 2-photon laser ablation. We further characterize the functional properties of 'first responder' cells by $\mathrm{NAD}(\mathrm{P}) \mathrm{H}$ autofluorescence, fluorescent recovery after photobleaching, glibenclamide stimulation, and network analysis. We also investigate which functional characteristics of these cells are critical by a computational model of islet electrophysiology. Based on the dynamics of $\left[\mathrm{Ca}^{2+}\right]$ responses, first responder cells are distinct from previously identified functional subpopulations. The first-phase response time of $\beta$ cells is spatially organized, dependent on the cell's distance to the first responder cells, and consistent over time up to $\sim 24 \mathrm{~h}$. First responder cells showed characteristics of high membrane excitability and slightly lower than average coupling to their neighbors. When first responder cells were ablated, the first-phase $\left[\mathrm{Ca}^{2+}\right]$ diminished, compared to ablating a random cell. We also observed a hierarchy of the first-phase response time, where cells that were next earliest to respond often take over the role of the first responder cell upon ablation. In summary, we discover and characterize a distinct first responder $\beta$-cell subpopulation, based on $\left[\mathrm{Ca}^{2+}\right]$ response timing, which is critical for the islet first-phase response to glucose.
\end{abstract}




\section{Introduction:}

Diabetes is a disease characterized by high blood glucose, caused by insufficient secretion of insulin. $\beta$-cells within pancreatic islets of Langerhans secrete insulin and are compromised in diabetes. Early work showed that in mechanically-dispersed islets, single $\beta$-cells are heterogeneous in the level of insulin release [1]. More recent studies have discovered markers that separate $\beta$ cells into distinct populations with differing functional properties. This includes markers that subdivides proliferative-competent $\beta$-cells from mature $\beta$-cells [2]; subdivides $\beta$-cells with different levels of insulin gene expression, granularity and secretion [3]; or subdivides $\beta$-cells that have differing responsiveness to insulin secretagogues [4]. Furthermore, single-cell highthroughput approaches such as scRNAseq or mass cytometry separate distinct $\beta$-cell populations $[5,6]$. However, the role of the heterogeneity in the function of the islet is poorly understood.

$\beta$-cells are excitable and show elevated electrical activity in response to glucose. Following metabolism of glucose, ATP-sensitive potassium channels $\left(\mathrm{K}_{\mathrm{ATP}}\right)$ close, depolarizing the membrane. This membrane depolarization opens voltage-gated calcium channels, elevating intracellular free $\mathrm{Ca}^{2+}$ activity $\left(\left[\mathrm{Ca}^{2+}\right]\right)$ and triggering insulin release. $\beta$-cells are electrically coupled to neighboring $\beta$-cells via Connexin36 (Cx36) gap junction channels [7-11], which enables the direct exchange of cations between $\beta$-cells [12]. Under low glucose conditions, gap junction channels transmit hyperpolarizing currents that suppress islet electrical activity and insulin release [13-15]. Under elevated glucose gap junction channels coordinate the oscillatory dynamics of islet electrical activity, thereby enhancing first phase insulin and pulsatile second phase insulin, and glucose tolerance $[11,16]$.

Gap junction coupling is non-uniform throughout the islet [17]. $\beta$-cells are also heterogeneous in glucose metabolism and excitability [18]. As a result, at low glucose some $\beta$ cells are suppressed more than others by hyperpolarizing currents transmitted from neighboring cells [19]. Conversely at elevated glucose, some $\beta$-cells are recruited and/or coordinated more than others by depolarizing currents transmitted from neighboring cells. As such, the response of each $\beta$-cell within the islet to glucose is different, reflecting both its intrinsic heterogeneity and its context within the islet. Several studies have sought to identify and characterize functional subpopulations of $\beta$-cells within the islet based on the $\left[\mathrm{Ca}^{2+}\right]$ response under glucose stimulation, together with the use of optogenetic based constructs and laser ablation. For example, $\beta$-cells that 
show significantly increased connectivity, termed 'hubs' or 'hub cells' [20,21], disproportionately suppressed islet $\left[\mathrm{Ca}^{2+}\right]$ following targeted hyper-polarization via optogenetic stimulation. Conversely a population of $\beta$-cells disproportionately activated islet $\left[\mathrm{Ca}^{2+}\right]$ following targeted depolarization via optogenetic stimulation [22]. Furthermore, cells that show $\left[\mathrm{Ca}^{2+}\right]$ oscillations that precede the rest of the islet, termed leader cells or wave-origin [22-24], have also been suggested to drive the oscillatory dynamics of $\left[\mathrm{Ca}^{2+}\right]$. While the precise mechanisms of this functional $\beta$-cell heterogeneity and its disproportionate control over islet function are under debate [25-27], it is important to note that the aspects of islet function implicated are all within the second phase, once steady state conditions are established.

Both in rodents and in human, first and second phases of insulin secretion have been distinguished $[28,29]$. Glucose-stimulated $\mathrm{Ca}^{2+}$ influx into the cell is necessary for both first and second phases of insulin secretion [30]. $\beta$-cell $\left[\mathrm{Ca}^{2+}\right]$ is also bi-phasic [31] and is correlated with insulin secretion dynamics [32]. The first phase of $\left[\mathrm{Ca}^{2+}\right]$ following low-to-high glucose is transitional, where cells with intrinsic differences in metabolic activity or other properties may be responding differently. The second phase of $\left[\mathrm{Ca}^{2+}\right]$ at high glucose is steady-state where the majority of cells are equally likely to fire [14], but with $\left[\mathrm{Ca}^{2+}\right]$ oscillations showing differing amplitudes, temporal delay (phase lag), and oscillation frequency [33, 34]. While different $\beta$-cell subpopulations have been examined during this second phase of $\left[\mathrm{Ca}^{2+}\right]$, the role of functional subpopulations during the first-phase of $\left[\mathrm{Ca}^{2+}\right]$ has not been examined. The first-phase insulin secretion becomes diminished in the absence of $\mathrm{Cx} 36$ gap junction coupling [16], pointing to the need for $\beta$-cell interactions to drive a coordinated first-phase secretion. Disruptions to first-phase insulin secretion is also a hallmark of type 2 diabetes $[35,36]$, showing similar responses to the absence of Cx36.

Here we identify $\beta$-cell subpopulations based on their dynamics during the first-phase of $\left[\mathrm{Ca}^{2+}\right]$ and test whether they disproportionately affect islet function. We address what mechanisms underlie their properties and disproportionate effect on islet function and ask whether they overlap with other identified $\beta$-cell subpopulations. 


\section{Results:}

First responder cells are distinct from other cell subpopulations associated with second-phase $\left[\mathrm{Ca}^{2+}\right]$. We first sought to identify $\beta$-cell populations that may exert control over the first-phase $\left[\mathrm{Ca}^{2+}\right]$ response, and test whether they differ from cells reported to control the second-phase $\left[\mathrm{Ca}^{2+}\right]$ response. $\left[\mathrm{Ca}^{2+}\right]$ dynamics were recorded continuously before and after glucose stimulation in islets isolated from Mip-Cre ${ }^{\text {ER}}$; Rosa-Stop-Lox-Stop-GCamP6s mice ( $\beta$-GCamP6s) that show $\beta$ cell specific GCamP6s expression following tamoxifen-induced CreER-mediated recombination. Islets from these $\beta$-GCamP6s mice demonstrated a bi-phasic $\left[\mathrm{Ca}^{2+}\right]$ response to glucose elevation (Fig. 1 A), with the first-phase characterized by a steep $\left[\mathrm{Ca}^{2+}\right]$ rise and subsequent plateau (Fig1 B). We quantified the response time for this $\left[\mathrm{Ca}^{2+}\right]$ rise for each cell and defined the "first responder" cells as the $10 \%$ of $\beta$-cells which responded earliest to glucose elevation (see methods). The "last responder" cells were defined as the $10 \%$ of $\beta$-cells which responded latest following glucose elevation. During the second, oscillatory phase (Fig.1 C) we quantified the phase of the $\left[\mathrm{Ca}^{2+}\right]$ wave. The "wave-origin" cells were defined as $10 \%$ of all cells with highest negative phase lag, which corresponds to showing an earlier $\left[\mathrm{Ca}^{2+}\right]$ oscillation. The "wave-end" cells were defined as $10 \%$ of all cells with highest positive phase lag, which corresponds to showing a later $\left[\mathrm{Ca}^{2+}\right]$ oscillation. On average, first responder cells were located $\sim 4$ cells away from wave-origin cells and $\sim 5$ cells away from wave end cells (Fig.1 D), indicating these cells are spatially distinct. The response time of $\beta$-cells in the islet following glucose stimulation was also dependent on their relative proximity to a first responder cell (Fig.1 E). Cells closer to first responder cells responded earlier which suggests that the first-phase $\left[\mathrm{Ca}^{2+}\right]$ dynamics are spatially organized (see also Fig. S2 A).

We next further examined the overlap between properties of cells defined by the first-phase and second-phase $\left[\mathrm{Ca}^{2+}\right]$ dynamics. The first-phase response time of first responders (Fig. 1F) was significantly different from the wave-origin $(\mathrm{p}=0.0300)$ and wave-end $(\mathrm{p}=0.0071)$ cells (Fig. $1 \mathrm{G})$; which themselves were no different from the islet average. Similarly, the phase lag of the $\left[\mathrm{Ca}^{2+}\right]$ wave of the first responders (Fig. $1 \mathrm{H}$ ) was not different from the islet average and thus showed a substantially different phase from the wave-origin cells $(p=0.0002)$ and the wave-end cells $(p<0.0001)$ (Fig1I). Therefore, the first- and second-phases of the $\left[\mathrm{Ca}^{2+}\right]$ response to glucose emerge in spatially and functionally distinct sub-regions of the islet, suggesting that the mechanisms governing the two phases of the $\left[\mathrm{Ca}^{2+}\right]$ response are different. 
During the second, oscillatory phase highly connected "hub cells" have been implicated in maintaining $\left[\mathrm{Ca}^{2+}\right]$ elevations. To assess whether first responder cells (and wave-origin/end cell subpopulations) overlap with these "hub cells", we identified $\beta$-cell hubs via network analysis as performed previously [20]. We separately performed this network analysis during the first-phase and second-phase $\left[\mathrm{Ca}^{2+}\right]$ dynamics. $\left[\mathrm{Ca}^{2+}\right]$ dynamics were more synchronized during the transitionary first phase (Fig.S1 A-F). The cumulative link probability distribution for the firstphase $\left[\mathrm{Ca}^{2+}\right]$ response was analogous to that reported by Stozer et al [21], where large numbers of functional connections per cell were much less probable than a small number of connections (Fig.S1 G). This was also found for the second-phase of $\left[\mathrm{Ca}^{2+}\right]$ response (Fig.S1 H) [20]. Importantly, highly connected cells identified during the transitionary first phase were different from those identified during the steady-state second phase (Fig.S1 I, J). We thus differentiated the "hub-like (p.1)", identified during the first-phase $\left[\mathrm{Ca}^{2+}\right]$ response, and "hub-like (p.2)" cells, identified during the second-phase $\left[\mathrm{Ca}^{2+}\right]$ response. During the first-phase $\left[\mathrm{Ca}^{2+}\right]$, first responder cells did not show a higher number of links compared to the islet average, unlike hub-like (p.1) cells (Fig.1 J, K). Interestingly, hub-like (p.1) cells did show an earlier response time to glucose, which was not significantly different from that of first responder cells (Fig.1 L). Thus, hub-like (p.1) cells partially overlap with first responder cells. During the second-phase $\left[\mathrm{Ca}^{2+}\right]$, first responder cells again did not show a higher number of links compared to the islet average, unlike “hub-like (p.2)" cells (Fig.1 M, N). Thus, first responder cells do not overlap with conventionally defined "hub-like (p.2)" cells.

First responder cells are consistent under physiological stimulation. We next sought to determine whether an early response time was a consistent feature of first responder cells. We performed both short term $(\sim 2 \mathrm{~h})$ and long term $(48 \mathrm{~h})$ experiments with repeatable glucose elevation. We reasoned that if cells respond randomly to glucose stimulation, then first responder cells identified during the original glucose elevation will not be the same first responder cells during a subsequent glucose elevation. Conversely if there exists a functional hierarchy of cells within the islet defining the first-phase response, then there should be consistency in the response time.

We first stimulated islets to elevated $(11 \mathrm{mM})$ glucose, lowered back to basal levels and re-stimulated over the course of 1-2 h (Fig.2 A). Upon initial stimulation, the response time of cells was skewed towards later times; whereas during the repeated stimulation the response time 
was symmetrical around the median time (Fig.2 B). There was a significant correlation between the response time of a cell during the initial stimulation as compared to the response time upon the repeated stimulation $(\mathrm{p}<0.0001)$. The majority of first responder cells retained their spatial position (Fig.2 D) and their earlier response time compared to the islet-average (p=0.0003) (Fig.2 E), indicating this subpopulation is consistent. In contrast, the last-responding cells lacked any consistency upon repeated glucose elevation, with a response time close to the islet-average (Fig.2 F). $\sim 50 \%$ of the original first responder cells remained first responder cells during the repeated glucose elevation, whereas only $\sim 20 \%$ of the original last responding cells remained last responding cells during the repeated glucose elevation (Fig.2 G).

To test whether first responder cells are maintained over a longer timescale, we measured the response time upon elevated glucose within the same cell layer in the islet for $48 \mathrm{~h}$ at $6 \mathrm{~h}$ intervals. At each time point we defined the first responder and last responder cells (Fig.2 H). There was no significant difference in the amplitude of the islet $\left[\mathrm{Ca}^{2+}\right]$ elevation at each time point (Fig.2 I). The first responder cells remained consistent during the first 12 hours, where they showed significantly earlier $\left[\mathrm{Ca}^{2+}\right]$ response time than the islet average. However, at $18-24 \mathrm{~h}$ the first responder cells become less distinguishable from the islet average, and at $>30 \mathrm{~h}$, their response time was indistinguishable from the islet-average (Fig.2 J). A similar temporal pattern was observed for the last responding cells (Fig.2 K). Thus, not all $\beta$-cells respond randomly to glucose stimulation. Rather, a first responder $\beta$-cell state consistently leads this response.

First responder cells show characteristics of more excitable cells. Small subpopulations of $\beta$-cells that have been previously identified to disproportionately recruit or maintain elevated $\left[\mathrm{Ca}^{2+}\right]$ in neighboring cells have shown elevated excitability, such as arising from increased metabolic activity [22]. We next examined characteristics of the first responder cells that may allow them to show an earlier response time. We first tested whether first responder cells have differing $\mathrm{K}_{\mathrm{ATP}}$ activity (for example, lower conductance that would increase the likelihood of earlier membrane depolarization in response to glucose elevation). We performed sequential glucose and glibenclamide stimulation, in the same manner as repeated glucose stimulation experiments. Following each stimulation, we identified first responder cells (Fig.3 A). There was a significant correlation between the response time of a cell during glucose stimulation as compared to the response time upon glibenclamide stimulation $(p<0.006)$. However, this correlation was weaker 
than that observed upon repeated glucose stimulation (Fig.3 B). Those cells which responded first to glucose, also responded earlier to glibenclamide (Fig.3 C, D) and showed a significantly lower than average response time to glibenclamide $(\mathrm{p}=0.04602)$ (Fig.3 E), consistent with our hypothesis. In contrast, those cells which responded last to glucose, did not show a response time different to the islet average under glibenclamide (Fig.3 F). This is equivalent to their lack of consistency under repeated glucose stimulation (Fig.2). On average $23 \%$ of the first responder cells under glucose stimulation remained first responder cells under glibenclamide stimulation, with only $\sim 7 \%$ of last responder cells remaining (Fig. $3 \mathrm{G}$ ). This suggested that while differing $\mathrm{K}_{\mathrm{ATP}}$ conductance is important factor in defining the earlier response time for a first responder cell, other factors are also involved.

To discover other factors that may characterize first responder cells, we first examined the $\left[\mathrm{Ca}^{2+}\right]$ elevation upon glucose stimulation (Fig.4 A). First responder cells demonstrated significantly higher influx of $\left[\mathrm{Ca}^{2+}\right]$ during the first-phase $\left[\mathrm{Ca}^{2+}\right]$ response, $(\mathrm{p}=0.0064)$ (Fig.4 B, C). First responder cells did not have a greater than average $\mathrm{NAD}(\mathrm{P}) \mathrm{H}$ levels at either low $(2 \mathrm{mM})$ or elevated (11 mM) glucose (Fig.4 D, E). Interestingly, following dye transfer kinetics via FRAP first responder cells showed lower than average gap junction permeability (Fig.4 F, G).

First responder cells drive first-phase $\left[\mathrm{Ca}^{2+}\right]$ elevation. To address whether a hierarchy of cell responsiveness is underlined by the response time in the islet, we removed specific $\beta$-cells from the islet via two-photon induced femtosecond laser ablation. Two-photon laser ablation allows for highly targeted removal of a cell without disrupting cells in close proximity [37]. As previously, we measured $\left[\mathrm{Ca}^{2+}\right]$ dynamics upon elevation from $2 \mathrm{mM}$ to $11 \mathrm{mM}$ glucose; lowered glucose back to $2 \mathrm{mM}$, ablated one cell, and then repeated glucose elevation (Fig.5 A). Under each glucose elevation we identified first responder cells (Fig.5 B). Upon ablation of a control (non- first responder) cell the overall islet $\left[\mathrm{Ca}^{2+}\right]$ response was relatively unchanged, with robust secondphase $\left[\mathrm{Ca}^{2+}\right]$ oscillations (Fig.5 A, B). Upon ablation of a first responder cell robust second-phase $\left[\mathrm{Ca}^{2+}\right]$ oscillations were also observed (Fig.5 C). However, a new cell within the islet become the first responder cell (Fig.5 D).

We examined the $\left[\mathrm{Ca}^{2+}\right]$ response timing and elevation of cells across the islet during the first-phase $\left[\mathrm{Ca}^{2+}\right]$ elevation following ablation of a control (non- first responder) cell or first responder cell. Following ablation of the control cell, the response time of first responder cells 
remained below the islet-average (Fig.5 E, p=0.0022); whereas last responder cells were not different from the islet average (Fig.5 F). On average 53\% of the original first responder cells remained as the earliest responding cells (Fig.5 G). These findings are very similar to those in the absence of any cell ablation (Fig.2). Following ablation of a first responder cell, the response time of the next earliest responder cells remained below the islet-average (Fig.5 H, p=0.0019); whereas last responder cells again were not different from the islet average (Fig.5 I). On average 40\% of the original next earliest responding cells ('second responder' cells) become new earliestresponding cells (Fig.5 J) and in another $20 \%$ of cases they remained as second responder cells. This suggests a certain hierarchy in the $\beta$-cell responsiveness to glucose.

We next quantified the effect of control or first responder cell ablation on the first-phase $\left[\mathrm{Ca}^{2+}\right]$ response. We first defined the $\left[\mathrm{Ca}^{2+}\right]$ influx as the area under the curve for $\left[\mathrm{Ca}^{2+}\right]$ over 5 min following elevation (Fig. $5 \mathrm{~K}$ ). We observed a size-dependence in area under the curve in both control and first responder ablation cell experiments (Fig.S2 C), hence we separated islets into small and large islets based on the median of the size distribution (Fig.S2 D). In large islets $\left(>89 \mu \mathrm{m}\right.$ diameter) the islet-average $\left[\mathrm{Ca}^{2+}\right]$ influx was not different between control or first responder cell ablation cases (Fig.5 L). In small islets $(<89 \mu \mathrm{m}$ diameter) while the islet-average $\left[\mathrm{Ca}^{2+}\right]$ influx decreased following ablation of each cell type, the decrease was significantly greater following ablation of first responder cells. Consistent with these observations the proportion of cells that showed elevated first-phase $\left[\mathrm{Ca}^{2+}\right]$ (i.e. within 5 min. of $\left[\mathrm{Ca}^{2+}\right]$ elevation) was largely unchanged in large islets, with $93 \%$ of cells showing elevated $\left[\mathrm{Ca}^{2+}\right]$ for ablation of both first responder or control cells (Fig.5 M). In small islets the proportion of cells that showed elevated first-phase $\left[\mathrm{Ca}^{2+}\right]$ was largely unchanged following control cell ablation (91\% of cells), but substantially decreased following first responder cell ablation ( $42 \%$ of cells). A similar trend was observed in terms of connectivity during the first-phase $\left[\mathrm{Ca}^{2+}\right]$ elevation: the mean number of functional links within the islet was significantly less following first responder cell ablation compared to the islet following control cell ablation, but only in the small islets (Fig.5 N). Thus, in smaller islets, removal of a first responder cell via fs laser ablation diminishes the elevation of first-phase $\left[\mathrm{Ca}^{2+}\right]$ as a result of there being fewer cells that respond both rapidly and in a coordinated fashion. 
Computer model description of first responder cell characteristics. To understand which characteristics of first responder cells are required for their action we utilized a previously published multi-cell model of islet $\beta$-cell electrophysiology [38]. This model incorporates heterogeneity in multiple metabolic, electrical and gap junctional characteristics. We simulated the $\left[\mathrm{Ca}^{2+}\right]$ response upon elevated glucose (Fig. $\left.6 \mathrm{~A}\right)$ and observed significant variability in the time of $\left[\mathrm{Ca}^{2+}\right]$ elevation as in experiments (Fig. 6 B). We defined first responders as the $10 \%$ of all cells with the fastest response times, as in experiments. We first examined the characteristics of these first responder cells in the model islet. The rate of glycolysis for model first responder cells was not significantly different from the islet-average (Fig.6 C), consistent with NAD(P)H measurements. The open channel $\mathrm{K}_{\mathrm{ATP}}$ conductance (equivalent to channel number) for model first responder cells was significantly lower than the islet-average (Fig.6 D), in agreement with the consistent response time under glibenclamide stimulation. The coupling conductance for model first responder cells was slightly, but significantly lower than the islet average (Fig6 E), consistent with gap junction permeability FRAP experiments. Model last responder cells also showed no difference in glycolysis rate, elevated $\mathrm{K}_{\text {ATP }}$ conductance and reduced coupling conductance (Fig. 6 C-E). Thus, model first responder cells are characterized by a combination of both lower electrical coupling and higher membrane excitability following lower open channel $\mathrm{K}_{\mathrm{ATP}}$ conductance.

To investigate the relative role of these functional characteristics to define first responder cells, we simulated the $\left[\mathrm{Ca}^{2+}\right]$ response following each of the above-mentioned parameters being adjusted to be equal to the corresponding islet-average parameter (Fig.6 F-H). That is, little change in glycolysis rate, increase in $\mathrm{K}_{\mathrm{ATP}}$ conductance or increase in coupling conductance. Thus, if a specific parameter is necessary for the function of the first responder, re-adjusting that parameter would be expected to significantly change the response time of that cell. Of the three parameters examined, re-adjusting the $\mathrm{K}_{\mathrm{ATP}}$ conductance had the greatest impact on the first responder cell response time (Fig.6 I) and whether a first responder cell showed the earliest $\left[\mathrm{Ca}^{2+}\right]$ elevation (Fig. $6 \mathrm{~J})$. In addition, rearrangement of the cell position within the islet significantly disrupted whether a first responder cell showed the earliest elevation in $\left[\mathrm{Ca}^{2+}\right]$ (Fig. 6K). Thus, model first responder cells are defined both by their increased excitability and their position within the islet.

Finally, we tested whether gap junction coupling was sufficient for first responder cells to recruit neighboring cells to show rapidly coordinated elevations in $\left[\mathrm{Ca}^{2+}\right]$. Following simulation of the islet, we removed either a random set of control cells or the earliest responding cells and re- 
simulated the islet $\left[\mathrm{Ca}^{2+}\right]$ response. Consistent with experimental measurements, removal of first responder cells diminished the area under the curve for the islet-average $\left[\mathrm{Ca}^{2+}\right]$ elevation, whereas removing a random set of cells had no impact on the islet-average $\left[\mathrm{Ca}^{2+}\right]$ elevation (Fig. $6 \mathrm{~L}$ ). Importantly a decrease in $\left[\mathrm{Ca}^{2+}\right]$ elevation was only observed for removal of greater than $10 \%$ of the earliest-responding cells; with greater reduction for removal of a higher $\%$ of cells. Thus, gap junction coupling is sufficient for a population of first responder cells to exert control over firstphase $\left[\mathrm{Ca}^{2+}\right]$ in the islet. 


\section{Discussion}

$\beta$-cells within the islet are functionally heterogeneous. While subpopulations of $\beta$-cells have been suggested to maintain coordinated oscillatory $\left[\mathrm{Ca}^{2+}\right]$ and insulin release [39], these are associated with the second phase of the $\left[\mathrm{Ca}^{2+}\right]$ response; a point at which cell-cell electrical communication is less important for regulating insulin release. Given the critical importance of cell-cell electrical communication in regulating first-phase insulin release [16], we examined whether there exists a subpopulation of $\beta$-cells associated with the first-phase electrical response. We discovered a subpopulation that we termed "first responder" cells that lead the first-phase $\left[\mathrm{Ca}^{2+}\right]$ response and did not overlap with other previously identified functional subpopulations of $\beta$-cells. This unique population is a more excitable population that was critical for recruiting $\beta$-cells to elevate $\left[\mathrm{Ca}^{2+}\right]$ immediately following glucose stimulation. We further demonstrated that this population represents a state of the $\beta$-cell that is conserved over a $\sim 24 \mathrm{~h}$ time period.

\section{First responder cells represent a distinct functional state of the $\beta$-cell:}

We defined first responder cells as those $\beta$-cells that lead the first-phase $\left[\mathrm{Ca}^{2+}\right]$ response. Importantly upon repeat stimulation, the same cells consistently showed earlier responses (Fig.2), unlike cells that showed later responses which lacked any consistency. Thus, the first responder $\left[\mathrm{Ca}^{2+}\right]$ signature is robust and allows identification of a functional cell subpopulation.

We demonstrated that first responder cells lack any overlap with other functional subpopulations of $\beta$-cells that are defined by $\left[\mathrm{Ca}^{2+}\right]$ signatures. Wave-origin and wave-end regions of the islet have been associated with regulating second phase $\left[\mathrm{Ca}^{2+}\right]$ dynamics $[22,23]$; where their identification is very similar to that of 'leader cells' [24], albeit identified with a different algorithm. Hub cells have been associated with maintaining elevated, coordinated $\left[\mathrm{Ca}^{2+}\right]$. Thus, the heterogeneity that controls second-phase $\left[\mathrm{Ca}^{2+}\right]$ and thus insulin release is very different than the first-phase $\left[\mathrm{Ca}^{2+}\right]$ and thus insulin release. This may be a result of different intrinsic and extrinsic factors that influence the $\beta$-cells during these different phases: first-phase insulin release is generally associated with electrical responses, but other amplifying factors, including intra-islet paracrine factors are generally associated with the second phase. Interestingly we did observe a partial overlap between first responder cells and $\beta$-cell hubs defined during the first phase (as opposed to the second phase where 'hub cells' have previously been defined). We observed 
differences in connectivity and the position of $\beta$-cell hubs between first and second phases (Fig.S1 I, J). Glucose regulates Cx36 gap junction coupling [23] and time-dependent changes in gap junction conductance may drive differences in connectivity and subpopulations between phases. Irrespective of the precise mechanisms, our findings indicate a fundamental difference between the way $\beta$-cell heterogeneity controls first and second phases. We do note that hub cells were previously identified following more rapid measurements of $\left[\mathrm{Ca}^{2+}\right]$ dynamics $(\sim 10 \mathrm{fps})$ than in our study here $(\sim 1 \mathrm{fps})[20]$. The lack of fast $(<1 \mathrm{~s})$ timescale $\left[\mathrm{Ca}^{2+}\right]$ dynamics in our analysis may therefore exclude some hub cells and mean that the hub-like (p2) cells we identify are not exactly analogous to those previously identified.

While the first-responder cells were consistent over $1 \mathrm{~h}$, this consistency was gradually lost after 24h (Fig.2). The overall responsiveness of the islet was maintained, indicating the loss of state is not simply due to islet dysfunction. This finding suggests that first responder cells represent a transient functional state of the islet and not a well-defined sub-type of the $\beta$-cell. We are not aware of other long term imaging studies beyond 1-2 $\mathrm{h}$ that test whether other functional subpopulations represent transient states of the $\beta$-cell rather than true $\beta$-cell subtypes. The current lack of genetic markers for first responder cells hinders robust lineage tracing approaches to validate this finding. Indeed, this first-responder cell state may represent a sub-set of the more mature functional cell sub-types that have been genetically marked [2]. Cyclic expression of Ins 2 gene activity has been reported in subsets of $\beta$-cells [41], suggesting that transient states of the $\beta$ cell can exist. A correlation between Ins expression and GJD2 (coding Cx36) expression has also been demonstrated [42]. Thus, we speculate that fluctuations in Cx36 expression may contribute to first responder cells: increases in Cx36 gap junction conductance would suppress first responder cells as a result of hyper-polarization by less excitable neighboring cells. Decreases in Cx36 gap junction conductance (as is observed in first responder cells, Fig.4) would allow the more excitable first responder cells to respond earlier and impact their neighboring cells. Notably elevated electrical activity and $\left[\mathrm{Ca}^{2+}\right]$ increases $G J D 2$ expression and increases $\mathrm{Cx} 36$ gap junction permeability [43], suggesting changes in excitability may mediate such transient activity.

An important consideration is that our study, along with other studies [20, 22], examine a single plane of cells within the islet. Thus, the first responder cells are relative to that islet region. It is quite likely that elsewhere in the islet at other planes, cells that respond earlier are present which may play a more important role. Thus, the first-responder cells we examine are not 
absolutely defined. Nevertheless, first responder cells represent a distinct functional state of the $\beta$ cell associated with regulating the first phase of $\left[\mathrm{Ca}^{2+}\right]$ and likely also insulin secretion.

\section{First responder cells represent a more excitable subpopulation:}

We hypothesized and demonstrated that first responder cells are important to recruit elevated $\left[\mathrm{Ca}^{2+}\right]$ in neighboring cells. Previously we identified highly-excitable cells that effectively recruited elevated $\left[\mathrm{Ca}^{2+}\right]$ in neighboring cells [22]. These cells showed increased NAD(P)H responses. However, while first responder cells showed increased $\left[\mathrm{Ca}^{2+}\right]$ elevation compared to neighboring cells, they did not show any difference in $\mathrm{NAD}(\mathrm{P}) \mathrm{H}$ levels (Fig.4). First responder cells however did show consistency following glibeclamide stimulation that inhibits $\mathrm{K}_{\text {ATP }}$ channels (Fig.3). Thus, first responder cells likely show differences in ion channel composition, including $\mathrm{K}_{\text {ATP. }}$ Other functional subpopulations (e.g 'hub cells', wave-origin) have been identified to show differences in glucose metabolism [20,22], which may also explain their lack of overlap with first responders.

We also found that gap junction permeability was lower in first responder cells. While somewhat paradoxical for a cell that interacts with its neighbors, lower gap junction conductance would prevent a cell being hyper-polarized and inhibited by less excitable neighboring cells. Indeed, theoretical studies have suggested that small populations of excitable cells with increased gap junction coupling would have less impact on islet function [40]. However, a certain level of gap junction conductance is needed: once significantly depolarized this gap junction conductance would be sufficient to carry depolarizing currents originating from the first responder cells.

Notably, we observed consistent results within our computational model of the islet (Fig.6). In the model, first responder cells showed decreased $\mathrm{K}_{\mathrm{ATP}}$ conductance but little difference in GK activity. Supporting this, disrupting $\mathrm{K}_{\mathrm{ATP}}$ conductance in the first responder cells led to other cells responding earlier. Thus, first responder cells are likely more excitable due to altered ion channel composition. We also observed in the model that the cell position within the islet was important: rearranging the position of the first responder cells disrupted their consistency. While technically challenging, dissociation of islets post-first responder cell identification, and association of islets into pseudo-islet structures would allow this property to be tested [44]. Nevertheless, we did observe that the first-phase response time is spatially organized within 2-3 cell layers further suggesting spatial positioning is important to generate first responder cells. 
As such first responder cells are more excitable cells, likely as a result of altered ion channel composition, as well as partially decreased gap junction coupling and/or spatial positioning within the islet.

First responder cells drive first phase $\left[\mathrm{Ca}^{2+}\right]$ elevation:

Following fs laser ablation of first responder cells we observed a decline in the first-phase $\left[\mathrm{Ca}^{2+}\right]$ response, in terms of the level of $\left[\mathrm{Ca}^{2+}\right]$ and the numbers of cells showing elevated $\left[\mathrm{Ca}^{2+}\right]$ (Fig.5). This indicates that first responder cells are necessary for recruiting elevated $\left[\mathrm{Ca}^{2+}\right]$ following glucose elevation. However, during the second-phase of $\left[\mathrm{Ca}^{2+}\right]$ elevation we still observed $\left[\mathrm{Ca}^{2+}\right]$ oscillations. Combining this finding with our discovery that different cells leading different phases of the $\left[\mathrm{Ca}^{2+}\right]$ response to glucose (first responders vs wave-origin), we conclude that first responder cells are more important for recruiting $\left[\mathrm{Ca}^{2+}\right]$ during a specific time window, and not for the longterm maintenance of $\left[\mathrm{Ca}^{2+}\right]$ elevation. Interestingly, this observation is similar to the regulation of $\left[\mathrm{Ca}^{2+}\right]$ by $\mathrm{Cx} 36$ gap junction channels. At elevated glucose almost all $\beta$-cells are capable of elevating $\left[\mathrm{Ca}^{2+}\right]$ and insulin release. However, some cells elevate $\left[\mathrm{Ca}^{2+}\right]$ and insulin release more rapidly and some elevate more slowly, likely as a result of being more or less excitable, respectively. As a result, while all cells elevate $\left[\mathrm{Ca}^{2+}\right]$, the differences in their timing prevents a robust first-phase insulin release [16]. Thus, we suggest that first responder cells being more excitable cells recruit less excitable cells to elevate $\left[\mathrm{Ca}^{2+}\right]$ in a more coordinated manner, thus enhancing first-phase $\left[\mathrm{Ca}^{2+}\right]$. However, they are subsequently not required for maintaining $\left[\mathrm{Ca}^{2+}\right]$ during second phase as a result of the intrinsic properties of $\beta$-cells in the islet.

We observed qualitatively similar results in the islet model after removal of firstresponding cells: the integrated $\left[\mathrm{Ca}^{2+}\right]$ elevation over the first phase was diminished (Fig.6). This indicates that gap junction coupling is sufficient to mediate the impact of first-responder cells over the islet response and is again consistent with the response in the absence of gap junction coupling. Recent modelling studies have questioned whether gap junction coupling is sufficient for other cell subpopulations to influence islet function [40]. For example, cells at the wave origin were shown to be less effective at pacing the oscillation frequency compared to cells at the wave end that drag the oscillation frequency; or the most excitable cells in the islet are less effective at maintaining elevations in $\left[\mathrm{Ca}^{2+}\right]$ compared to the least excitable cells that are more effective in suppressing elevations in $\left[\mathrm{Ca}^{2+}\right]$. 
While model results indicated that gap junction coupling was sufficient for $10 \%$ of first responder cells to drive first-phase $\left[\mathrm{Ca}^{2+}\right]$, we do note more substantial diminishments of $\left[\mathrm{Ca}^{2+}\right]$ were observed when greater numbers of earlier responding cells were removed. This suggests the existence of functional redundancy in the ability of earlier responding cells to drive the first-phase $\left[\mathrm{Ca}^{2+}\right]$ elevation. Indeed, following ablation of a first responding cell, the 'new' first responding cells were cells that responded earlier prior to cell ablation. This further explains how larger islets were relatively resistant to destruction of individual cells. However, in small islets the much greater impact on $\left[\mathrm{Ca}^{2+}\right]$ is likely as a result of both the greater $\%$ of the islet that has been disrupted, and that there are fewer earlier responding cells to replace the function of the first responder cell. Nevertheless, as noted elsewhere, by restricting our analysis to a single plane, as with other functional subpopulation studies, we are also potentially excluding cells that respond earlier and would be expected to show greater impact in controlling the first phase $\left[\mathrm{Ca}^{2+}\right]$. As such future studies should focus on full 3D analysis encompassing the whole islet.

\section{Summary:}

Several functional $\beta$-cell subpopulations have been identified that influence islet function, yet it is currently unknown whether these subpopulations overlap and whether the mechanisms by which they affect the islet function are the same. This understanding has been hindered by a lack of standard procedures in identifying functional subpopulations (e.g. by analysis of $\left[\mathrm{Ca}^{2+}\right]$ dynamics, optogenetic stimulation or silencing). Longer-term imaging to track the consistency and state of functional subpopulations has also been missing. We combined high resolution confocal microscopy in islets with $\beta$-cell specific $\left[\mathrm{Ca}^{2+}\right]$ sensor expression, together with targeted removal of single cells via 2-photon laser ablation and standardized analysis of $\left[\mathrm{Ca}^{2+}\right]$ coordination. We discovered a distinct functional $\beta$-cell state that was stable over $\sim 24 \mathrm{~h}$ and characterized by increased excitability and reduced gap junction permeability. This state did not overlap with other previously identified subpopulations. Removal of these cells disproportionately disrupted the response time of the islet and $\left[\mathrm{Ca}^{2+}\right]$ levels during the first phase following glucose elevation. Thus, we have identified a unique cell state/subpopulation that is functionally important to a phase of insulin release that is critical for glucose homeostasis and disrupted early in diabetes progression. 


\section{Methods:}

Animal care: Male and female mice were used under protocols approved by the University of Colorado Institutional Animal Care and Use Committee. $\beta$-cell-specific GCaMP6s expression ( $\beta$ GCaMP6s) was achieved through crossing a MIP-CreER (The Jackson Laboratory) and a GCaMP6s line (The Jackson Laboratory). Genotype was verified through qPCR (Transetyx, Memphis, TN). Mice were held in a temperature-controlled environment with a $12 \mathrm{~h} \mathrm{light/dark}$ cycle and given continuous access to food and water. CreER-mediated recombination was induced by 5 daily doses of tamoxifen $(50 \mathrm{mg} / \mathrm{kg}$ bw in corn oil) delivered IP.

Islet isolation and culture: Islets were isolated from mice under ketamine/xylazine anesthesia (80 and $16 \mathrm{mg} / \mathrm{kg}$ ) by collagenase delivery into the pancreas via injection into the bile duct. The collagenase-inflated pancreas was surgically removed and digested. Islets were handpicked and planted into the glass-bottom dishes (MatTek) using CellTak cell tissue adhesive (Sigma-Aldrich). Islets were cultured in RPMI medium (Corning, Tewksbury, MA) containing 10\% fetal bovine serum, $100 \mathrm{U} / \mathrm{mL}$ penicillin, and $100 \mathrm{mg} / \mathrm{mL}$ streptomycin. Islets were incubated at 37C, 5\% CO2 for 24-72 $\mathrm{h}$ before imaging.

Imaging: An hour prior to imaging nutrition media from the isolated islets was replaced by an imaging solution (125 mM NaCl, 5.7 mM KCl, $2.5 \mathrm{mM} \mathrm{CaCl} 2,1.2 \mathrm{mM} \mathrm{MgCl}$, $10 \mathrm{mM}$ HEPES, and $0.1 \% \mathrm{BSA}, \mathrm{pH} 7.4$ ) containing $2 \mathrm{mM}$ glucose. During imaging the glucose level was raised to $11 \mathrm{mM}$. Islets were imaged using either a LSM780 system (Carl Zeiss, Oberkochen, Germany) with a 40x 1.2 NA objective or with an LSM800 system (Carl Zeiss) with 20x 0.8 NA PlanApochromat objective or a 40x 1.2 NA objective, with samples held at 37C.

For $\left[\mathrm{Ca}^{2+}\right]$ measurements GCaMP6s fluorescence was excited using a 488-nm laser. Images were acquired at 1 frame/s at 10-15 um depth from the bottom of the islet. Glucose was elevated 3 minutes after the start of recording, unless stated otherwise.

$\mathrm{NAD}(\mathrm{P}) \mathrm{H}$ autofluorescence and $\left[\mathrm{Ca}^{2+}\right]$ dynamics were performed in the same z-position within the islet. $\mathrm{NADH}(\mathrm{P}) \mathrm{H}$ autofluorescence was imaged under two-photon excitation using a tunable mode-locked Ti:sapphire laser (Chameleon; Coherent, Santa Clara, CA) set to $710 \mathrm{~nm}$. Fluorescence emission was detected at 400-450 nm using the internal detector. Z-stacks of 6-7 images were acquired spanning a depth of $5 \mu \mathrm{m}$. First the NAD(P)H was recorded at $2 \mathrm{mM}$ 
glucose, then the $\left[\mathrm{Ca}^{2+}\right]$ dynamics was recorder at $2 \mathrm{mM}$ and during transition to $11 \mathrm{mM}$ glucose. After the $\left[\mathrm{Ca}^{2+}\right]$ wave was established, the NAD(P)H was recorded at $11 \mathrm{mM}$ glucose.

Cx36 gap junction permeability and $\left[\mathrm{Ca}^{2+}\right]$ dynamics were performed in the same zposition within the islet, with gap junction permeability measured using fluorescence recovery after photobleaching, as previously described [17]. After $\left[\mathrm{Ca}^{2+}\right]$ imaging, islets were loaded with $12 \mathrm{mM}$ Rhodamine-123 for $30 \mathrm{~min}$ at $37 \mathrm{C}$ in imaging solution. Islets were then washed and FRAP performed at $11 \mathrm{mM}$ glucose at room temperature. Rhodamine-123 was excited using a 488-nm laser line, and fluorescence emission was detected at 500-580 $\mathrm{nm}$. Three baseline images were initially recorded. A region of interest was then photobleached achieving, on average, a 50\% decrease in fluorescence, and images were then acquired every 5-15 s for $15 \mathrm{~min}$.

Imaging long term $\left[\mathrm{Ca}^{2+}\right]$ dynamics: The initial $\left[\mathrm{Ca}^{2+}\right]$ dynamics under glucose elevation from 2 to $11 \mathrm{mM}$ at 0 hours was recorded. The dish was marked to indicate its orientation with respect to the microscope stage, and the arrangement of islets was noted to facilitate islet localization in subsequent imaging. After this first time point, imaging solution was replaced by the islet culture media and the dish was kept in the incubator at 37C and 5\% CO2 until the next time point. The same cell layer in the islet was imaged at $6 \mathrm{~h}$ intervals until $48 \mathrm{~h}$. For some islets intervals of $12 \mathrm{~h}$ were recorded.

Laser ablation: Laser ablation was performed with two-photon tunable mode-locked Ti:sapphire laser (Chameleon; Coherent, Santa Clara, CA) set to $750 \mathrm{~nm}$. First $\left[\mathrm{Ca}^{2+}\right]$ dynamics was recorded at $2 \mathrm{mM}$ and $11 \mathrm{mM}$ glucose, and first responder cells were identified. Then glucose was lowered to $2 \mathrm{mM}$ and $\left[\mathrm{Ca}^{2+}\right]$ activity was monitored to ensure the islet returns to a basal level of activity. The first responder cell(s) were identified, and a sub-cell-sized region of interest to be ablated (5x5 $\mu \mathrm{m}$ ) was selected either over the first responder cell or over a control cell far from the first responder. Ablation was performed by illuminating the region of interest. $\left[\mathrm{Ca}^{2+}\right]$ dynamics were then imaged during the transition from $2 \mathrm{mM}$ to $11 \mathrm{mM}$ glucose.

Analysis of $\left[\mathrm{Ca}^{2+}\right]$ dynamics: We defined first responder cells as $10 \%$ of the cells imaged within an islet that responded earliest to show elevated $\left[\mathrm{Ca}^{2+}\right]$. The time of response was defined as time at which intensity of the fluorescence of the $\left[\mathrm{Ca}^{2+}\right]$ indicator (GCaMP6s) reached half the 
maximum height following islet stimulation by glucose or other secretagogue. We refer to this time as half-height time, or response time throughout the text.

The wave origin and wave end cells were defined during the second-phase $\left[\mathrm{Ca}^{2+}\right]$ response to glucose, once oscillations emerge. These cells were defined based on the phase lag of the slow $\left[\mathrm{Ca}^{2+}\right]$ oscillation in each cell with respect to the phase of the average $\left[\mathrm{Ca}^{2+}\right]$ oscillation across the islet, as previously presented [45].

For analysis of long term $\left[\mathrm{Ca}^{2+}\right]$ dynamics, only those cells that correspond to cells imaged in the first time point $(0 \mathrm{~h})$ were considered. These cells were identified by locating their relative positions with respect to non- $\beta$ cells which did not express GCaMP6s. Additional cells that appear in the plane of as a result of islets slowly flattening over time were not considered.

Network analysis: Network connectivity analysis presented in Fig.1 and Fig. S1was performed as reported previously [20] separately for first-phase and second-phase $\left[\mathrm{Ca}^{2+}\right]$ response. Briefly, $\left[\mathrm{Ca}^{2+}\right]$ time courses were binarized based on intensity deviation from the mean intensity using $20 \%$ intensity cutoff. Intensity above this cutoff was assigned a value of 1 , and below - value of 0 . A co-activity matrix with elements $\mathrm{C}_{\mathrm{ij}}$ for each cell pair in the islet was constructed from the binarized signal.

$$
\mathrm{C}_{i j}=\frac{\mathrm{T}_{i j}}{\sqrt{\mathrm{T}_{i} \mathrm{~T}_{j}}}
$$

The $\mathrm{T}_{\mathrm{i}}$ and $\mathrm{T}_{\mathrm{j}}$ represent time (sec) of activity (when intensity was $>20 \%$ cutoff) for cells $i$ and $j$, and the $\mathrm{T}_{\mathrm{ij}}$ represents time of co-activity of a cell pair. Then the co-activity matrix was shuffled $>9999$ times to construct a random co-activity matrix, with elements $\mathrm{C}_{\mathrm{ij}}{ }^{*}$, which was used to account for a co-activity being due to chance. The experimental co-activity matrix was then adjusted using threshold constructed of the mean value of $\mathrm{C}_{\mathrm{ij}}{ }^{*}$ and a standard deviation from the mean, $\sigma^{*}$ :

$$
\mathrm{Thr}_{i j}=\mathrm{C}_{i j}^{*}+2 \sigma^{*}
$$

Pearson-product-based network analysis presented in Fig. 5 was performed as previously reported [21]. $\left[\mathrm{Ca}^{2+}\right]$ time courses were analyzed during time intervals identical to those used to identify first responders. The Pearson product for each cell pair in the islet was calculated over each time point, and the time-average values were computed to construct a correlation matrix. An adjacency matrix was calculated by applying a threshold to the correlation matrix. The same 
threshold of 0.9 was applied to all islets. All cell pairs with a non-zero values in the adjacency matrix were considered to have a functional link.

Islet modelling: The coupled $\beta$-cell model was described previously [46] and adapted from the published Cha-Noma single cell model [47, 48]. All code was written in $\mathrm{C}++$ and run on the SUMMIT supercomputer (University of Colorado Boulder).

The membrane potential $\left(V_{i}\right)$ for each $\beta$-cell $\mathrm{i}$ is related to the sum of individual ion currents as described by [47]:

$$
\begin{aligned}
& \mathrm{C}_{\mathrm{m}} \frac{\mathrm{dV}_{\mathrm{i}}}{\mathrm{dt}}=\mathrm{I}_{\mathrm{Cav}}+\mathrm{I}_{\mathrm{TRPM}}+\mathrm{I}_{\mathrm{SOC}}+\mathrm{I}_{\mathrm{bNSC}}+\mathrm{I}_{\mathrm{KDr}}+\mathrm{I}_{\mathrm{KCa}(\mathrm{SK})} \\
& +\mathrm{I}_{\mathrm{K}_{\mathrm{ATP}}}+\mathrm{I}_{\mathrm{NaK}}+\mathrm{I}_{\mathrm{NaCa}}+\mathrm{I}_{\mathrm{PMCA}}+\mathrm{I}_{\mathrm{NaCa}}+\mathrm{I}_{\mathrm{Coup}}
\end{aligned}
$$

Where the gap junction mediated current $\mathrm{I}_{\text {Coup }}[19]$ is:

$$
\mathrm{I}_{\text {Coup }}=\sum_{\mathrm{i}} \mathrm{g}_{\text {Coup }}^{\mathrm{ij}}\left(\mathrm{V}_{\mathrm{i}}-\mathrm{V}_{\mathrm{j}}\right)
$$

There are $\mathrm{N}=1000$ cells in each simulation. Heterogeneity was introduced by randomizing multiple variables according to a Gaussian distribution (Table S1). Heterogeneity in Cx36 gap junctions was modeled as a $\gamma$-distribution with parameters $\mathrm{k}=\theta=4$ as described previously [22] and scaled to an average $g_{\text {Coup }}$ between cells $=120 \mathrm{pS}$.

The flux of glycolysis $\mathrm{J}_{\mathrm{glc}}$, which is limited by the rate of $\mathrm{kglc}_{\mathrm{gl}}$ activity in the $\beta$-cell, is described as:

$$
\mathrm{J}_{\mathrm{glc}}=\mathrm{k}_{\mathrm{glc}} \cdot \mathrm{f}_{\mathrm{glc}} \cdot\left(\left[\mathrm{Re}_{\mathrm{tot}}\right]-[\mathrm{Re}]\right)
$$

Where $\mathrm{k}_{\mathrm{glc}}$ is the maximum rate of glycolysis (equivalent to GK activity), which was simulated as a continuous Gaussian distribution with a mean of $0.000126 \mathrm{~ms}^{-1}$ and standard deviation of $25 \%$ of the mean. $\left[\mathrm{Re}_{\text {tot }}\right]=10 \mathrm{mM}$, the total amount of pyrimidine nucleotides. The ATP and glucose dependence of glycolysis (GK activity) is:

$$
f_{\text {glc }}=\frac{1}{1+\frac{K_{\mathrm{mATP}}}{[\mathrm{ATP}]_{\mathrm{i}}}} \cdot \frac{1}{1+\left(\frac{\mathrm{K}_{\mathrm{G}}}{[\mathrm{G}]}\right)^{\mathrm{hgl}}}
$$

Where $[\mathrm{G}]$ is the extracellular concentration of glucose, hgl is the hill coefficient, $\mathrm{K}_{\mathrm{G}}$ is the half maximal concentration of glucose, and $\mathrm{K}_{\mathrm{mATP}}$ is the half maximal concentration of ATP.

In simulations where a specific heterogenous parameter is adjusted, the first 100 responding cells were determined in a simulation (see below), and these first responder cells were adjusted so that the parameter of choice ( $\mathrm{g}_{\mathrm{KATP}}, \mathrm{kglc}_{\mathrm{gl}}$, or $\left.\mathrm{g}_{\mathrm{Coup}}\right)$ was forced to be at the average value 
(Table S1). The value of the parameter of the other cells in the islet was adjusted so that the average of the parameter value over the islet remained unchanged. A new simulation with these adjusted parameters was run. As a control, a random set of 100 cells are distributed across the islet, and these random cells were selected with the same spatial organization as first responder cells from a simulation that initiated with a different random number seed. These random cells are adjusted in the same way as described above to the average parameter value, while the other cells in the simulation are adjusted so that the average islet value remains unchanged.

Islet modelling analysis: All simulation data analysis was performed using custom MATLAB scripts. First responder cells were determined using the $\left[\mathrm{Ca}^{2+}\right]$ time courses of each cell during the first 20-72 seconds, which covers the first phase $\left[\mathrm{Ca}^{2+}\right]$ response. The response time was calculated as the time to half the maximum $\left[\mathrm{Ca}^{2+}\right]$ level. First responder cells were then determined to be the $100(10 \%)$ cells with the earliest response time.

In simulations where cells are uncoupled, a given \% of cells with the lowest response time are uncoupled from the simulation, but the next 100 cells are analyzed as the first responders of this new simulation. To uncouple cells from the simulated islet, the conductance, gCoup, of the cells to be removed is set to $0 \mathrm{pS}$. Removed cells are excluded from subsequent islet analysis. For control simulations a random $\%$ of cells are uncoupled from the islet. These cells are distributed across the islet in the same organization as the first responder cells from a different simulation.

Statistical analysis: All statistical analysis was performed in Prism (GraphPad). For computational results a one-way repeated measures ANOVA with Tukey post-hoc analysis was utilized to test for significant differences between either the WT simulation or a 'Random' control simulation that matched islets before and after parameters are adjusted or cells are uncoupled. For experimental results either one-way ANOVA, or a two-tailed t-test were used (indicated in figure captions) to compare parameters of a specific $\beta$-cell subpopulation to the corresponding islet-average parameters. Data is reported as mean \pm s.e.m. (standard error in the mean) unless otherwise indicated. Linear regression analysis was presented as the trend with 95\% confidence intervals. The difference of the slope from zero was evaluated with the F test and the p value was reported. 


\section{Acknowledgments:}

Richard KP Benninger (University of Colorado) is the guarantor of this work and, as such, had full access to all the data in the study and takes responsibility for the integrity of the data and the accuracy of the data analysis. All authors acknowledge that no conflict of interest exists. This work was supported by Juvenile Diabetes Research Foundation (JDRF) Grant 5-CDA-2014-198-A-N; National Institute of Health (NIH) grants R01 DK102950, R01 DK106412 (to RKPB); by JDRF grant 3-PDF-2019-741-A-N (to VK); by NIH grant F31 DK126360 (to JMD). D.J.H. was supported by a Diabetes UK R.D. Lawrence (12/0004431) Fellowship, a Wellcome Trust Institutional Support Award, and MRC (MR/N00275X/1 and MR/S025618/1) and Diabetes UK (17/0005681) Project Grants. This project has received funding from the European Research Council (ERC) under the European Union's Horizon 2020 research and innovation programme (Starting Grant 715884 to D.J.H.). The funders had no role in the study design, data collection and analysis, decisions to publish, or preparation of the manuscript.

\section{Author Contributions:}

VK conceived of the idea, designed and performed experiments and computer simulations, analyzed data, wrote the manuscript; JMD performed computer simulations, analyzed data, edited text; WES performed animal surgeries, analyzed data; DJH analyzed data, edited the manuscript; RAP performed animal surgeries; AD analyzed data; MSI analyzed data; RKPB conceived of the idea, designed experiments, and wrote the manuscript. 


\section{References}

[1] D. Salomon and P. Meda, "Heterogeneity and contact-dependent regulation of hormone secretion by individual B cells," (in eng), Exp Cell Res, vol. 162, no. 2, pp. 507-20, Feb 1986, doi: 10.1016/0014-4827(86)90354-x.

[2] E. Bader et al., "Identification of proliferative and mature $\beta$-cells in the islets of Langerhans," (in eng), Nature, vol. 535, no. 7612, pp. 430-4, 07 2016, doi: 10.1038 /nature18624.

[3] H. Katsuta et al., "Subpopulations of GFP-marked mouse pancreatic $\beta$-cells differ in size, granularity, and insulin secretion," (in eng), Endocrinology, vol. 153, no. 11, pp. 5180-7, Nov 2012, doi: 10.1210/en.2012-1257.

[4] M. Karaca et al., "Exploring functional beta-cell heterogeneity in vivo using PSA-NCAM as a specific marker," (in eng), PLoS One, vol. 4, no. 5, p. e5555, 2009, doi: 10.1371/journal.pone.0005555.

[5] Å. Segerstolpe et al., "Single-Cell Transcriptome Profiling of Human Pancreatic Islets in Health and Type 2 Diabetes," (in eng), Cell Metab, vol. 24, no. 4, pp. 593-607, 10 2016, doi: 10.1016/j.cmet.2016.08.020.

[6] Y. J. Wang et al., "Multiplexed In Situ Imaging Mass Cytometry Analysis of the Human Endocrine Pancreas and Immune System in Type 1 Diabetes," (in eng), Cell Metab, vol. 29, no. 3, pp. 769-783.e4, 03 2019, doi: 10.1016/j.cmet.2019.01.003.

[7] L. Michon et al., "Involvement of gap junctional communication in secretion," (in eng), Biochim Biophys Acta, vol. 1719, no. 1-2, pp. 82-101, Dec 2005, doi: 10.1016/j.bbamem.2005.11.003.

[8] S. Bavamian et al., "Islet-cell-to-cell communication as basis for normal insulin secretion," (in eng), Diabetes Obes Metab, vol. 9 Suppl 2, pp. 118-32, Nov 2007, doi: 10.1111/j.14631326.2007.00780.x.

[9] V. Serre-Beinier et al., "Cx36 preferentially connects beta-cells within pancreatic islets," (in eng), Diabetes, vol. 49, no. 5, pp. 727-34, May 2000, doi: 10.2337/diabetes.49.5.727.

[10] R. K. Benninger, M. Zhang, W. S. Head, L. S. Satin, and D. W. Piston, "Gap junction coupling and calcium waves in the pancreatic islet," (in eng), Biophys $J$, vol. 95, no. 11, pp. 5048-61, Dec 2008, doi: 10.1529/biophysj.108.140863.

[11] M. A. Ravier et al., "Loss of connexin36 channels alters beta-cell coupling, islet synchronization of glucose-induced $\mathrm{Ca} 2+$ and insulin oscillations, and basal insulin release," (in eng), Diabetes, vol. 54, no. 6, pp. 1798-807, Jun 2005, doi: 10.2337/diabetes.54.6.1798.

[12] A. P. Moreno, V. M. Berthoud, G. Pérez-Palacios, and E. M. Pérez-Armendariz, "Biophysical evidence that connexin-36 forms functional gap junction channels between pancreatic mouse beta-cells," (in eng), Am J Physiol Endocrinol Metab, vol. 288, no. 5, pp. E948-56, May 2005, doi: 10.1152/ajpendo.00216.2004.

[13] S. Speier, A. Gjinovci, A. Charollais, P. Meda, and M. Rupnik, "Cx36-mediated coupling reduces beta-cell heterogeneity, confines the stimulating glucose concentration range, and affects insulin release kinetics," (in eng), Diabetes, vol. 56, no. 4, pp. 1078-86, Apr 2007, doi: $10.2337 / \mathrm{db} 06-0232$.

[14] R. K. Benninger, W. S. Head, M. Zhang, L. S. Satin, and D. W. Piston, "Gap junctions and other mechanisms of cell-cell communication regulate basal insulin secretion in the pancreatic islet," (in eng), J Physiol, vol. 589, no. Pt 22, pp. 5453-66, Nov 2011, doi: 10.1113/jphysiol.2011.218909. 
[15] J. V. Rocheleau et al., "Critical role of gap junction coupled KATP channel activity for regulated insulin secretion," (in eng), PLoS Biol, vol. 4, no. 2, p. e26, Feb 2006, doi: 10.1371/journal.pbio.0040026.

[16] W. S. Head, M. L. Orseth, C. S. Nunemaker, L. S. Satin, D. W. Piston, and R. K. Benninger, "Connexin-36 gap junctions regulate in vivo first- and second-phase insulin secretion dynamics and glucose tolerance in the conscious mouse," (in eng), Diabetes, vol. 61, no. 7, pp. 1700-7, Jul 2012, doi: 10.2337/db11-1312.

[17] N. L. Farnsworth, A. Hemmati, M. Pozzoli, and R. K. Benninger, "Fluorescence recovery after photobleaching reveals regulation and distribution of connexin36 gap junction coupling within mouse islets of Langerhans," (in eng), J Physiol, vol. 592, no. 20, pp. 443146, Oct 2014, doi: 10.1113/jphysiol.2014.276733.

[18] D. G. Pipeleers, "Heterogeneity in pancreatic beta-cell population," (in eng), Diabetes, vol. 41, no. 7, pp. 777-81, Jul 1992, doi: 10.2337/diab.41.7.777.

[19] T. H. Hraha, M. J. Westacott, M. Pozzoli, A. M. Notary, P. M. McClatchey, and R. K. Benninger, "Phase transitions in the multi-cellular regulatory behavior of pancreatic islet excitability," PLoS Comput Biol, vol. 10, no. 9, p. e1003819, Sep 2014, doi: 10.1371/journal.pcbi.1003819.

[20] N. R. Johnston et al., "Beta Cell Hubs Dictate Pancreatic Islet Responses to Glucose," (in eng), Cell Metab, vol. 24, no. 3, pp. 389-401, 09 2016, doi: 10.1016/j.cmet.2016.06.020.

[21] A. Stožer et al., "Functional connectivity in islets of Langerhans from mouse pancreas tissue slices," (in eng), PLoS Comput Biol, vol. 9, no. 2, p. e1002923, 2013, doi: 10.1371/journal.pcbi.1002923.

[22] M. J. Westacott, N. W. F. Ludin, and R. K. P. Benninger, "Spatially Organized beta-Cell Subpopulations Control Electrical Dynamics across Islets of Langerhans," Biophys J, vol. 113, no. 5, pp. 1093-1108, Sep 5 2017, doi: 10.1016/j.bpj.2017.07.021.

[23] R. K. Benninger et al., "Intrinsic islet heterogeneity and gap junction coupling determine spatiotemporal $\mathrm{Ca}^{2+}$ wave dynamics," (in eng), Biophys J, vol. 107, no. 11, pp. 2723-33, Dec 2014, doi: 10.1016/j.bpj.2014.10.048.

[24] V. Salem et al., "Leader $\beta$-cells coordinate Ca," (in eng), Nat Metab, vol. 1, no. 6, pp. 615629, Jun 2019, doi: 10.1038/s42255-019-0075-2.

[25] L. S. Satin, Q. Zhang, and P. Rorsman, "'Take Me To Your Leader": An Electrophysiological Appraisal of the Role of Hub Cells in Pancreatic Islets," (in eng), Diabetes, vol. 69, no. 5, pp. 830-836, May 2020, doi: 10.2337/dbi19-0012.

[26] G. A. Rutter, N. Ninov, V. Salem, and D. J. Hodson, "Comment on Satin et al. "Take Me To Your Leader": An Electrophysiological Appraisal of the Role of Hub Cells in Pancreatic Islets. Diabetes 2020;69:830-836," (in eng), Diabetes, vol. 69, no. 9, pp. e10-e11, Sep 2020, doi: 10.2337/db20-0501.

[27] L. S. Satin and P. Rorsman, "Response to Comment on Satin et al. "Take Me To Your Leader": An Electrophysiological Appraisal of the Role of Hub Cells in Pancreatic Islets. Diabetes 2020;69:830-836," (in eng), Diabetes, vol. 69, no. 9, pp. e12-e13, Sep 2020, doi: 10.2337/dbi20-0027.

[28] D. L. Curry, L. L. Bennett, and G. M. Grodsky, "Dynamics of insulin secretion by the perfused rat pancreas," (in eng), Endocrinology, vol. 83, no. 3, pp. 572-84, Sep 1968, doi: 10.1210/endo-83-3-572. 
[29] D. Porte and A. A. Pupo, "Insulin responses to glucose: evidence for a two pool system in man," (in eng), J Clin Invest, vol. 48, no. 12, pp. 2309-19, Dec 1969, doi: 10.1172/JCI106197.

[30] J. C. Henquin, "Relative importance of extracellular and intracellular calcium for the two phases of glucose-stimulated insulin release: studies with theophylline," (in eng), Endocrinology, vol. 102, no. 3, pp. 723-30, Mar 1978, doi: 10.1210/endo-102-3-723.

[31] C. S. Nunemaker, D. H. Wasserman, O. P. McGuinness, I. R. Sweet, J. C. Teague, and L. S. Satin, "Insulin secretion in the conscious mouse is biphasic and pulsatile," (in eng), Am J Physiol Endocrinol Metab, vol. 290, no. 3, pp. E523-9, Mar 2006, doi: 10.1152/ajpendo.00392.2005.

[32] C. S. Nunemaker et al., "Individual mice can be distinguished by the period of their islet calcium oscillations: is there an intrinsic islet period that is imprinted in vivo?," (in eng), Diabetes, vol. 54, no. 12, pp. 3517-22, Dec 2005, doi: 10.2337/diabetes.54.12.3517.

[33] C. S. Nunemaker et al., "Glucose metabolism, islet architecture, and genetic homogeneity in imprinting of [Ca2+](i) and insulin rhythms in mouse islets," (in eng), PLoS One, vol. 4, no. 12, p. e8428, Dec 2009, doi: 10.1371/journal.pone.0008428.

[34] M. Zhang, P. Goforth, R. Bertram, A. Sherman, and L. Satin, "The Ca2+ dynamics of isolated mouse beta-cells and islets: implications for mathematical models," (in eng), Biophys J, vol. 84, no. 5, pp. 2852-70, May 2003, doi: 10.1016/S0006-3495(03)70014-9.

[35] E. Cerasi and R. Luft, "The plasma insulin response to glucose infusion in healthy subjects and in diabetes mellitus," (in eng), Acta Endocrinol (Copenh), vol. 55, no. 2, pp. 278-304, Jun 1967, doi: 10.1530/acta.0.0550278.

[36] S. N. Davis et al., "Proinsulin and insulin concentrations following intravenous glucose challenges in normal, obese, and non-insulin-dependent diabetic subjects," (in eng), Metabolism, vol. 42, no. 1, pp. 30-5, Jan 1993, doi: 10.1016/0026-0495(93)90168-n.

[37] A. Vogel and V. Venugopalan, "Mechanisms of pulsed laser ablation of biological tissues," (in eng), Chem Rev, vol. 103, no. 2, pp. 577-644, Feb 2003, doi: 10.1021/cr010379n.

[38] J. M. Dwulet et al., "How Heterogeneity in Glucokinase and Gap-Junction Coupling Determines the Islet [Ca," (in eng), Biophys J, vol. 117, no. 11, pp. 2188-2203, 12 2019, doi: 10.1016/j.bpj.2019.10.037.

[39] R. K. P. Benninger and D. J. Hodson, "New Understanding of $\beta$-Cell Heterogeneity and In Situ Islet Function," (in eng), Diabetes, vol. 67, no. 4, pp. 537-547, 04 2018, doi: 10.2337/dbi17-0040.

[40] J. M. Dwulet, J. K. Briggs, and R. K. P. Benninger, "Small subpopulations of $\beta$-cells do not drive islet oscillatory [Ca 2+ ] dynamics via gap junction communication," vol. https://doi.org/10.1101/2020.10.28.358457, ed. BioRXiv, 2020.

[41] H. Modi, "Ins2 gene bursting activity defines a mature $\beta$-cell state," BioRxiv, 2019.

[42] V. Serre-Beinier et al., "Cx36 makes channels coupling human pancreatic beta-cells, and correlates with insulin expression," (in eng), Hum Mol Genet, vol. 18, no. 3, pp. 428-39, Feb 2009, doi: 10.1093/hmg/ddn370.

[43] J. G. Miranda , W. E. Schleicher , D. G. Ramirez , S. P. Landgrave , and R. K. View ORCID Profile Benninger, "Dynamic changes in $\beta$-cell electrical activity and $[\mathrm{Ca} 2+$ ] regulates NFATc3 activation and downstream gene transcription," vol. https://doi.org/10.1101/2020.06.28.176768, ed. BioRXiv, 2020. 
[44] K. Shekiro , T. H. Hraha , A. B. Bernard , R. K. Benninger , and K. S. Anseth "Engineering Functional Pseudo-Islets of Defined Sizes from Primary Murine Cells Using PEG Microwell Devices," ed, 2020.

[45] M. J. Westacott, N. W. F. Ludin, and R. K. P. Benninger, "Spatially Organized $\beta$-Cell Subpopulations Control Electrical Dynamics across Islets of Langerhans," (in eng), Biophys J, vol. 113, no. 5, pp. 1093-1108, Sep 2017, doi: 10.1016/j.bpj.2017.07.021.

[46] J. M. Dwulet et al., "How Heterogeneity in Glucokinase and Gap-Junction Coupling Determines the Islet $[\mathrm{Ca}(2+)]$ Response," Biophys J, vol. 117, no. 11, pp. 2188-2203, Dec 3 2019, doi: 10.1016/j.bpj.2019.10.037.

[47] C. Y. Cha et al., "Ionic mechanisms and Ca2+ dynamics underlying the glucose response of pancreatic beta cells: a simulation study," (in English), J Gen Physiol, vol. 138, no. 1, pp. 21-37, Jul 2011, doi: DOI 10.1085/jgp.201110611.

[48] C. Y. Cha, E. Santos, A. Amano, T. Shimayoshi, and A. Noma, "Time-dependent changes in membrane excitability during glucose-induced bursting activity in pancreatic beta cells," (in eng), J Gen Physiol, vol. 138, no. 1, pp. 39-47, Jul 2011, doi: 10.1085/jgp.201110612. 


\section{Figure Captions}

Figure 1. Identification of first responder cells. A) Representative time-course of $\left[\mathrm{Ca}^{2+}\right]$ dynamics within an islet following glucose elevation (time $3 \mathrm{~min}$ ). B) First-phase of the $\left[\mathrm{Ca}^{2+}\right]$ response in $\mathrm{A}$, indicating the $\left[\mathrm{Ca}^{2+}\right]$ dynamics characterizing the first responder $\left(1^{\text {st }}\right.$-resp) and last responder (last-resp) cells compared to the islet-average. C) Second phase of the $\left[\mathrm{Ca}^{2+}\right]$ response in $\mathrm{A}$, indicating the $\left[\mathrm{Ca}^{2+}\right]$ dynamics characterizing the wave-origin (w-or) and wave-end (w-end) cells. D) Spatial location of the functional $\beta$-cell subpopulations within a representative islet (left) together with mean distances between the subpopulation and first responder ( $n=10$ islets). E) Correlation between the response time of each $\beta$-cell in the islet and their proximity to the first responder $\beta$-cell. Solid line indicates regression, dashed line indicates 95\% CI. F) False-color map indicating $\left[\mathrm{Ca}^{2+}\right]$ response time to glucose elevation during the first phase. $\left.\mathrm{G}\right)\left[\mathrm{Ca}^{2+}\right]$ response time following glucose elevation for different $\beta$-cell subpopulations ( $n=13$ islets) H) False-color map of the phase of the $\left[\mathrm{Ca}^{2+}\right]$ wave during the second phase. I) Phase lag of the $\left[\mathrm{Ca}^{2+}\right]$ wave for different $\beta$-cell subpopulations with respect to the islet-average ( $n=13$ islets). J) Link map based on the functional network analysis, computed during the first-phase of the $\left[\mathrm{Ca}^{2+}\right]$ response. Hublike (p1) cells are highlighted in red. K) Percent of functional links during the first-phase of $\left[\mathrm{Ca}^{2+}\right]$ response for different $\beta$-cell subpopulations ( $n=8$ islets). L) Response time for first responder cells and for hubs defined during the first phase ( $n=8$ islets). M) Link map based on the functional network analysis, computed during the second-phase $\left[\mathrm{Ca}^{2+}\right]$ response. Hub-like (p2) cells are highlighted in blue. N) Percent of functional links during the second-phase $\left[\mathrm{Ca}^{2+}\right]$ response for different $\beta$-cell subpopulations ( $\mathrm{n}=8$ islets). Statistical test: one-way ANOVA where $* * * *$ represents $\mathrm{p}<0.0001, * * * \mathrm{p}<0.001, * * \mathrm{p}<0.01, * \mathrm{p}<0.05$ indicated for comparison of the isletaverage value vs all other groups. In (E) linear regression analysis was applied with the slope being significantly different from 0 with $\mathrm{p}$ value $<0.0001$ calculated from F-statistic. Functional network analysis was performed via binarization and co-activity matrix analysis, as described [20].

Figure 2. Consistency of first responder cells. A) Representative time-course of $\left[\mathrm{Ca}^{2+}\right]$ dynamics within an islet under repeated glucose stimulation. Vertical scale bar represents $30 \%$ of the fluorescence intensity change. B) Distribution of the response time during first and repeated glucose elevation ( $\mathrm{n}=10$ islets). C) Correlation between the time of $\left[\mathrm{Ca}^{2+}\right]$ elevation upon initial glucose elevation for each $\beta$-cell and the time of $\left[\mathrm{Ca}^{2+}\right]$ elevation upon repeated glucose elevation 
( $n=12$ islets). D) Representative image of the islet with the location of first responders (red) and last responders (green) during initial and repeated glucose elevation. E) time of response of cells identified as first responders during the initial glucose elevation and upon repeated glucose elevation ( $\mathrm{n}=10$ islets). F) As in E for last responders. G) Pie chart indicating the percent of the original first and last responders that remain in their role during repeated glucose elevation. $\mathrm{H}$ ) False-color map indicating $\left[\mathrm{Ca}^{2+}\right]$ response time to glucose elevation during the first phase, recorded in the same region of the islet over 48 hours at 6 hour intervals. Scale bar indicates 20 $\mu \mathrm{m}$. I) Area under the curve for $\left[\mathrm{Ca}^{2+}\right]$ elevation over 0-5 min for the islet average, for each timewindow indicated. Data is normalized to the $\left[\mathrm{Ca}^{2+}\right]$ AUC at $\left.0 \mathrm{~h} . \mathrm{J}\right)$ time evolution of the response time of the cells identified as first and K) As in J for last responders ( $n=7$ islets). Statistical test: ordinary one-way ANOVA where $* * * *$ represents $\mathrm{p}<0.0001, * * * \mathrm{p}<0.001, * * \mathrm{p}<0.01, * \mathrm{p}<0.05$ indicated for comparison of the islet-average value vs all other groups. $\dagger$ in $(\mathrm{K})$ indicates significance of $p=0.06$. In $(C)$ linear regression analysis was applied with the slope being significantly different from 0 with $\mathrm{p}$ value $<0.0001$ calculated from $\mathrm{F}$ statistic.

Figure 3. Responsiveness of first responder cells to secretagogues. A) Representative timecourse of $\left[\mathrm{Ca}^{2+}\right]$ dynamics within an islet under $11 \mathrm{mM}$ glucose stimulation (dashed curve) and under $10 \mu \mathrm{M}$ glibenclamide (solid curve) stimulation for first responder cell (red) and islet-average (grey). B) Correlation between the time of $\left[\mathrm{Ca}^{2+}\right]$ elevation upon glucose stimulation for each $\beta$ cell and the time of $\left[\mathrm{Ca}^{2+}\right]$ elevation upon glibenclamide stimulation ( $\mathrm{n}=13$ islets). C) Representative image of the islet with the location of first responders (red) and last responders (green) during glucose and glibenclamide stimulation. Scale bar indicates $20 \mu \mathrm{m}$. D) time of response of cells identified as first responders during glucose stimulation and upon glibenclamide stimulation ( $\mathrm{n}=13$ islets). E) As in D for last responder cells. F) Pie chart indicating the percent of first and last responders that remain in their role during subsequent glibenclamide. Statistical test: paired two-tailed t-test where $* * * *$ represents $\mathrm{p}<0.0001, * * * \mathrm{p}<0.001, * * \mathrm{p}<0.01, * \mathrm{p}<0.05$ indicated for comparison of the islet-average value vs all other groups. $\dagger$ in $(\mathrm{K})$ indicates significance of $p=0.06$. In (B) linear regression analysis was applied with the slope being significantly different from 0 with $\mathrm{p}=0.0065$ calculated from $\mathrm{F}$ statistic. 
Figure 4. Characteristics of first responder cells. A) Representative image of the islet with first responders (red), wave-origin (blue) and wave-end (purple) indicated. B) Time course of $\left[\mathrm{Ca}^{2+}\right]$ elevation in each cell population, indicating Area under the curve. C) Area under the curve for each cell subpopulation during the first $3 \mathrm{~min}$ after $\left[\mathrm{Ca}^{2+}\right]$ elevation upon elevated glucose. D) Representative image of $\mathrm{NAD}(\mathrm{P}) \mathrm{H}$ autofluorescence in islet indicated in $\mathrm{A}$, at low $(2 \mathrm{mM})$ and high (11 mM) glucose. E) Mean NAD(P)H intensity in each identified subpopulation of $\beta$-cell, at low $(2 \mathrm{mM})$ and high $(11 \mathrm{mM})$ glucose, normalized with respect to the islet average ( $\mathrm{n}=10$ islets); F) Reprehensive GCamP6s fluorescence and Rhodamine123 fluorescence (for FRAP measurements) within the same islet layer. G) Mean Rhodamine123 fluorescence recovery rate as calculated during FRAP ( $\mathrm{n}=5$ islets). Scale bar indicates $20 \mu \mathrm{m}$. Statistical test: in (C) one-way ANOVA where $* * \mathrm{p}<0.01, * \mathrm{p}<0.05$ indicated for comparison of the islet-average value vs all other groups. In (G) paired two-tailed t-test where $* \mathrm{p}<0.05$ indicated for comparison of the isletaverage value vs first responder group.

Figure 5. Role of first responder cells. A) Representative time-course of $\left[\mathrm{Ca}^{2+}\right]$ dynamics within an islet pre- and post- ablation of a control cell (non-first responder cell). Vertical scale indicates $30 \%$ fluorescence intensity change. B) Representative image of the islet with the location of first responders (red) pre- and post- ablation of a control cell (red square). C) As in A for ablation of first responder cell. D) As in B for ablation of first responder cell (Red square), with second responder cell highlighted (orange). E) time of response of cells identified as first responders prior to control cell ablation and following control cell ablation ( $\mathrm{n}=10$ islets). F) As in E for last responders. G) Pie chart indicating the percent of the original first and last responders that remain in their role following control cell ablation. H) Time of response of cells identified as second responders prior to first responder cell ablation and following first responder cell ablation $(\mathrm{n}=10$ islets). I) As in $\mathrm{H}$ for last responders. J) Pie chart indicating the percent of the original second and last responders that remain in their role following first responder cell ablation. K) Representative time course of $\mathrm{Ca}^{2+}$ elevation following glucose elevation pre- and post- ablation, with the AreaUnder-the-Curve indicated. L) Area-Under-the-Curve for the first-phase $\left[\mathrm{Ca}^{2+}\right]$ response post ablation of a control and first responder cells, for small $(<89 \mu \mathrm{m}$ diameter) and large $(>89 \mu \mathrm{m}$ diameter) islets. Data is normalized to the Area-Under-the-Curve prior to ablation. M) \% of cells that show $\left[\mathrm{Ca}^{2+}\right]$ elevation post ablation of a control and first responder cells, for small and large 
islets. Data is normalized to the Area-Under-the-Curve prior to ablation; N) Number of functional links during the first-phase of $\left[\mathrm{Ca}^{2+}\right]$ response post ablation of a control and first responder cells, for small and large islets. Data is normalized to the number of functional links prior to ablation ( $\mathrm{n}=4-6$ islets). Functional network analysis was performed via Pearson-product algorithm, as described before [21]. Statistical test: paired two-tailed t-test where $* * * *$ represents $\mathrm{p}<0.0001, * * *$ $\mathrm{p}<0.001, * * \mathrm{p}<0.01, * \mathrm{p}<0.05$ indicated for comparison of the groups. $\dagger$ in $(\mathrm{E})$ indicates significance of $\mathrm{p}=0.06$.

Figure 6. Modelling first responder cells. A) Representative time-course of $\left[\mathrm{Ca}^{2+}\right]$ in a simulated islet, indicating the $\left[\mathrm{Ca}^{2+}\right]$ dynamics characterizing the first responder $\left(1^{\text {st }}\right.$-resp) and last responder (last-resp) cells compared to the islet-average. B) False-color map indicating $\left[\mathrm{Ca}^{2+}\right]$ response time to glucose elevation during the first phase. C) Mean parameter value of glycolysis rate ( $\left.\mathrm{k}_{\mathrm{glyc}}\right)$ averaged over the first (red) and last (green) indicated \% of responding cells ( $n=4$ seeds). Data is normalized with respect to the islet average parameter. D) As in C for $\mathrm{K}_{\text {ATP }}$ conductance ( $\mathrm{g}_{\text {KATP }}$ ). E) As in $\mathrm{C}$ for coupling conductance $\left(\mathrm{g}_{\text {coup }}\right)$. F) Distribution of the glycolysis rate $\left(\mathrm{k}_{\mathrm{glyc}}\right)$ in nonfirst responders (grey) and first responders (red) before (left) and after (right) parameter adjustment to set first responder parameter the same to the islet average value ( $n=5$ seeds). $G$ ) As in $F$ for adjustment of $\mathrm{K}_{\mathrm{ATP}}$ conductance ( $\left.\mathrm{g}_{\mathrm{KATP}}\right)$. $\mathrm{H}$ ) As in $\mathrm{F}$ for adjustment of coupling conductance ( $\left.\mathrm{g}_{\text {coup }}\right)$. I) Change in response time upon adjustment of the glycolysis rate $\left(\mathrm{k}_{\text {glyc }}\right), \mathrm{K}_{\mathrm{ATP}}$ conductance ( $\mathrm{g}_{\text {KATP }}$ ) and coupling conductance ( $\mathrm{g}_{\text {coup }}$ ) in first responder indicated in F-H, or in a random subset of cells. J) Percent of the original first responder cells that remain among the earliest responders after adjustment of adjustment of $\mathrm{k}_{\text {glyc }}$, $\mathrm{g}_{\text {KATP, }} \mathrm{g}_{\text {coup }}$ in first responder cells indicated in F-H. K) Percent of the original first responders that remain among the earliest responders after adjustment of the spatial position of the first responders in three separate distributions (spheres) ( $\mathrm{n}=5$ seeds). L) Decrease in the Area-Under-the-Curve (AUC) of the first phase of the $\mathrm{Ca}^{2+}$ response following de-coupling (removal) of a given \% of the first responder or a random set of cells from the islet ( $\mathrm{n}=5$ seeds). Statistical test: ordinary one-way ANOVA where $* * * *$ represents $\mathrm{p}<0.0001$, *** $\mathrm{p}<0.001, * * \mathrm{p}<0.01, * \mathrm{p}<0.05$ indicated for comparison of the groups. 


\section{Supplemental Figure Captions}

Figure S1. A) Example of cell co-activity matrix of an islet obtained for the first-phase of the $\left[\mathrm{Ca}^{2+}\right]$ response to glucose. B) As in A during the second phase. C) Adjacency matrix formed by applying a threshold to the co-activity matrix for the first phase. D) As in $\mathrm{C}$ for the second phase. E) Example of a network connectivity map based on the adjacency matrix for the first phase. F) As in $\mathrm{E}$ for the second phase. $\mathrm{G}$ ) cumulative link probability distribution ( $\mathrm{n}=8$ islets) plotted on a logarithmic scale for the first-phase $\left[\mathrm{Ca}^{2+}\right]$ response. $\left.\mathrm{H}\right)$ As in $\mathrm{G}$ for second-phase $\left[\mathrm{Ca}^{2+}\right]$ response. I) Percent of functional links during the first-phase of the $\left[\mathrm{Ca}^{2+}\right]$ response ( $\mathrm{n}=8$ islets). J) Percent of functional connections computed during the second-phase of the $\left[\mathrm{Ca}^{2+}\right]$ response ( $\mathrm{n}=8$ islets). $\mathrm{K})\left[\mathrm{Ca}^{2+}\right]$ response time to glucose elevation for different $\beta$-cell subpopulations ( $\mathrm{n}=8-10$ islets). $\mathrm{L}$ ) Phase lag of the $\mathrm{Ca}^{2+}$ wave with respect to the islet-average wave for different $\beta$-cell subpopulations ( $\mathrm{n}=8-12$ islets). Functional network analysis was performed via binarization and co-activity matrix analysis, as described before [20]. Statistical test: ordinary one-way ANOVA where ${ }^{* * * *}$ represents $\mathrm{p}<0.0001,{ }^{* * *} \mathrm{p}<0.001,{ }^{* *} \mathrm{p}<0.01,{ }^{*} \mathrm{p}<0.05$ indicated for comparison of the groups.

Figure S2. A) Dependence of the time of response of cells on their distance to the first responder cell ( $\mathrm{n}=8$ islets). B) $\mathrm{NAD}(\mathrm{P}) \mathrm{H}$ at $11 \mathrm{mM}$ glucose as function of distance from the first responder cell ( $n=4$ islets). C) Islet size dependence of the $\left[\mathrm{Ca}^{2+}\right]$ influx into the islet (area under the curbe of the $\left[\mathrm{Ca}^{2+}\right]$ time-course) for random and first responder ablation cases. D) Size distribution of the islets studied in the ablation experiments.

Table S1. Values of heterogeneous parameters used in the islet simulations. 
bioRxiv preprint doi: https://doi.org/10.1101/2020.12.22.424082; this version posted December 24, 2020. The copyright holder for this preprint (which was not certified by peer review) is the author/funder. All rights reserved. No reuse allowed without permission.
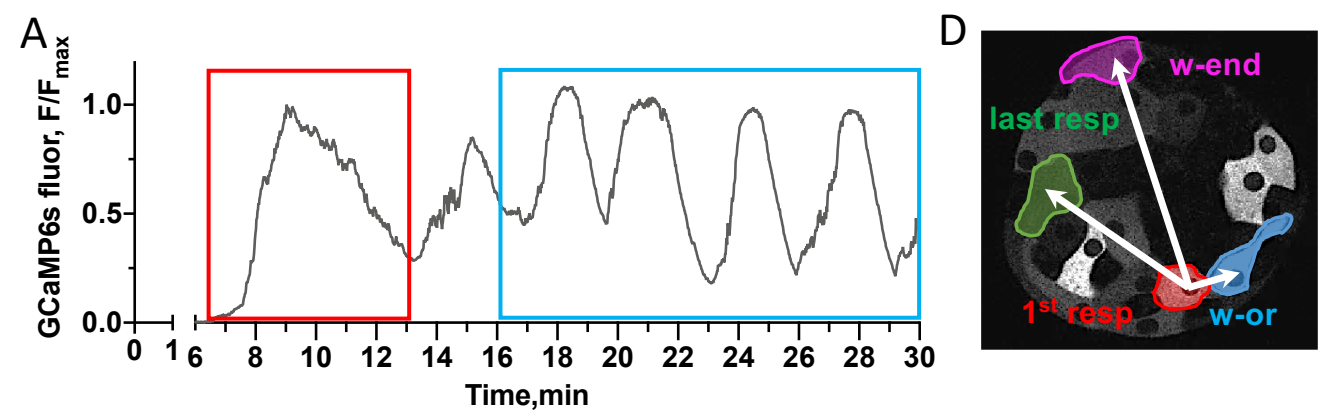

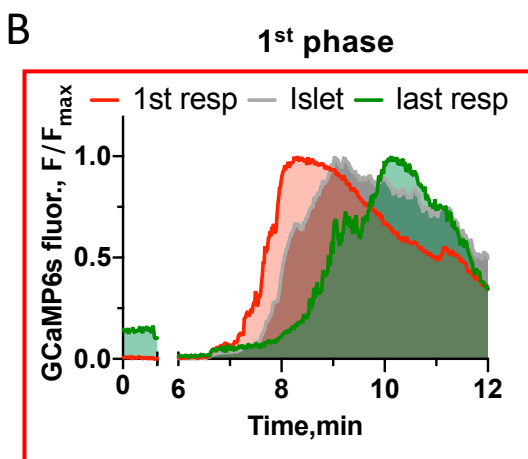

C $2^{\text {nd }}$ phase
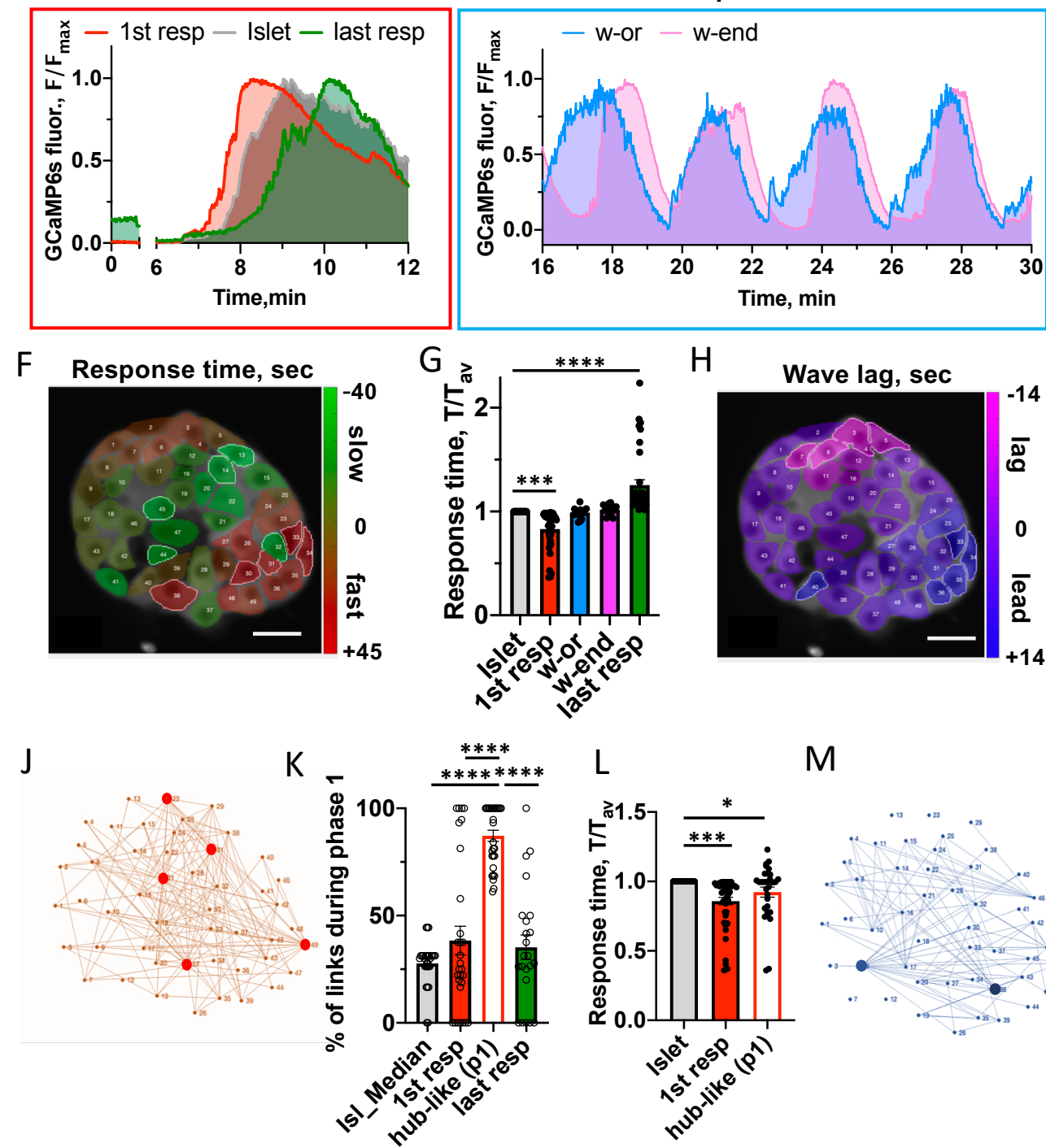

M
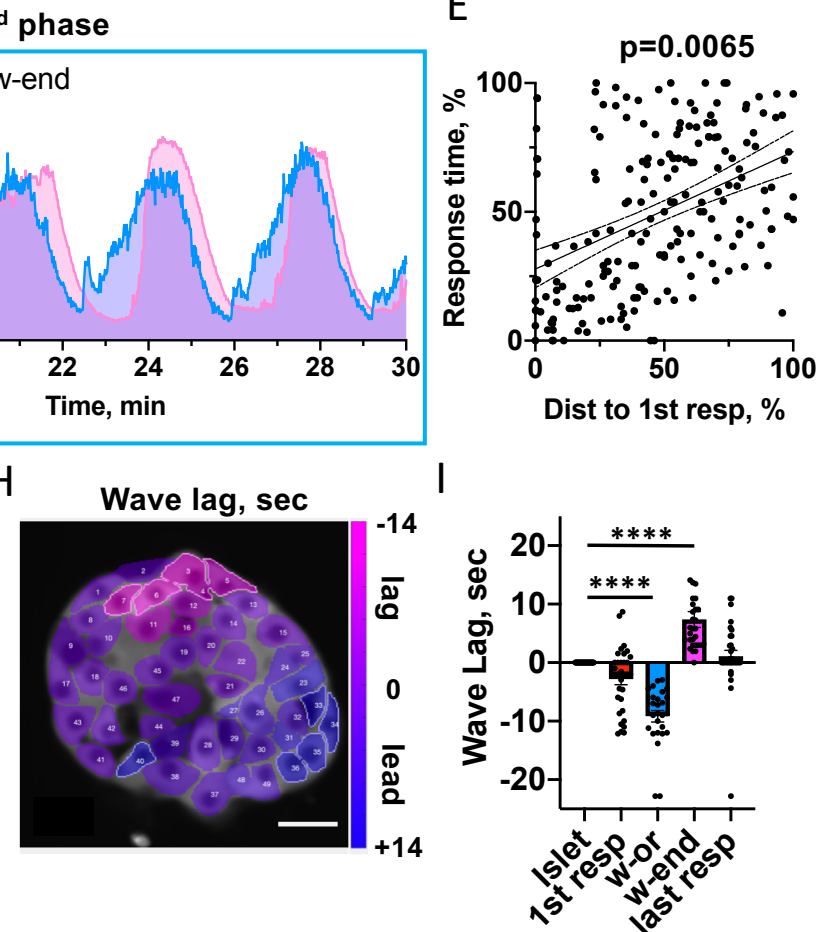

$\mathrm{N}$

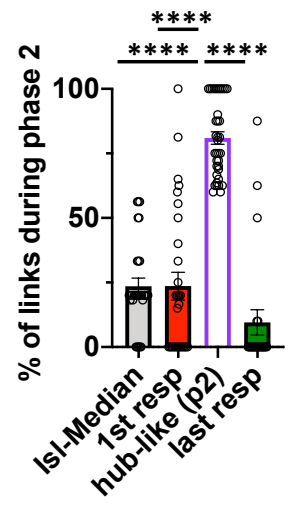

Figure 1 

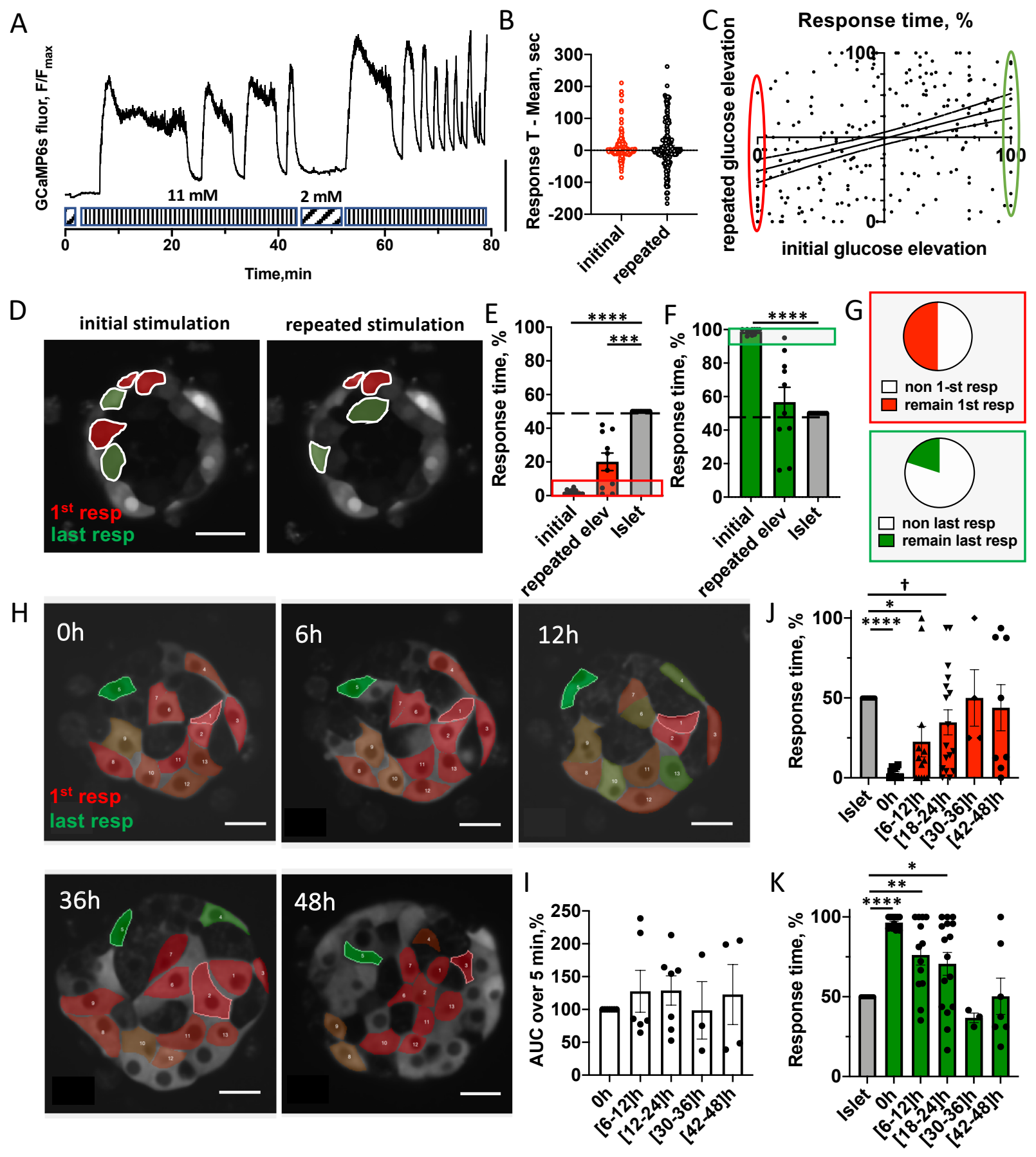

Figure 2 
A

A

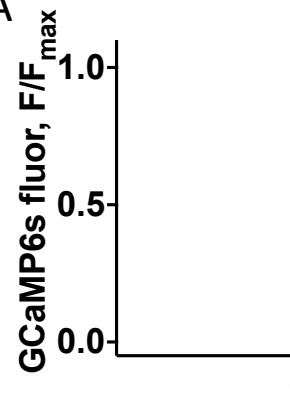

C

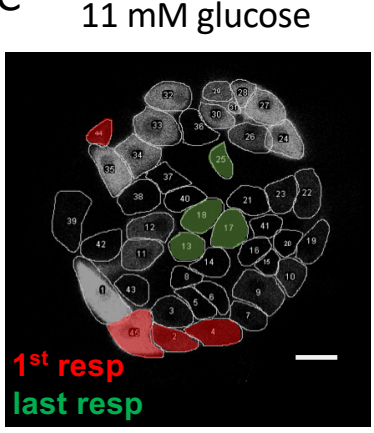

B

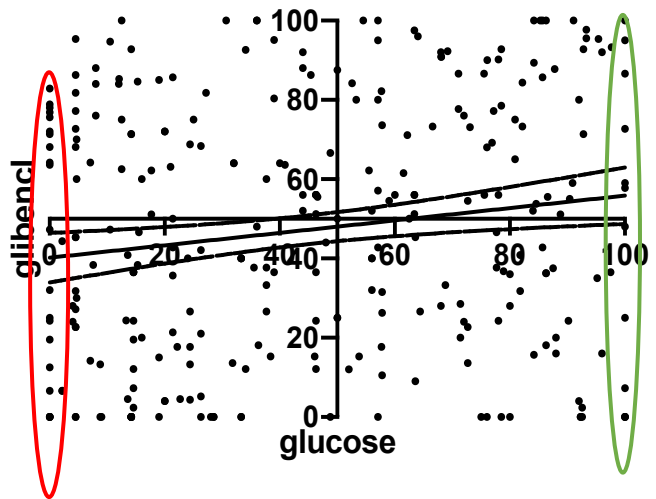

D

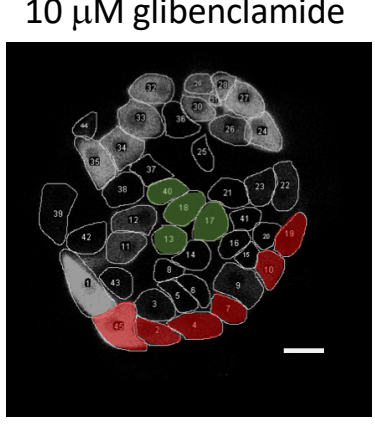

E

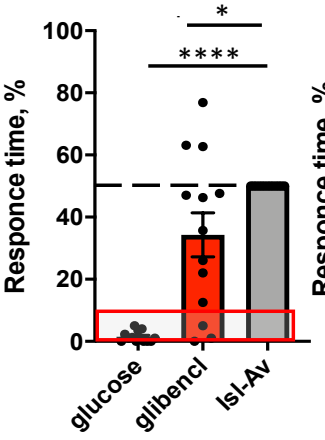

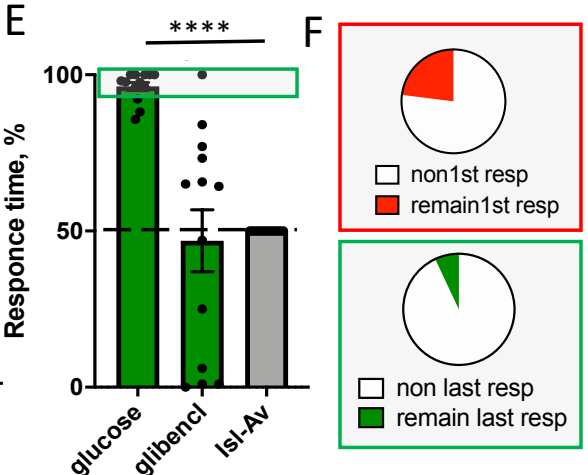

Figure 3 
bioRxiv preprint doi: https://doi.org/10.1101/2020.12.22.424082; this version posted December 24,2020 . The copyright holder for this preprint (which was not certified by peer review) is the author/funder. All rights reserved. No reuse allowed without permission.

A

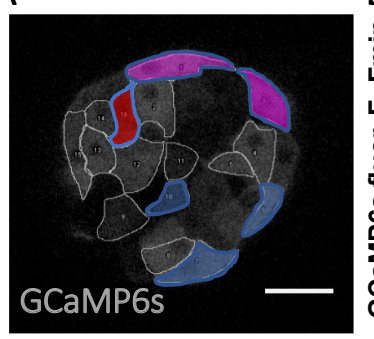

$\mathrm{D}$

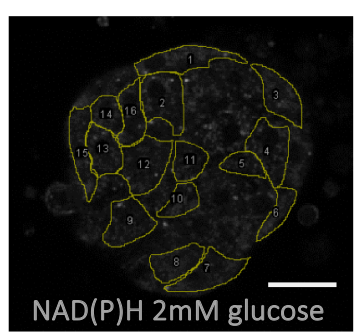

F

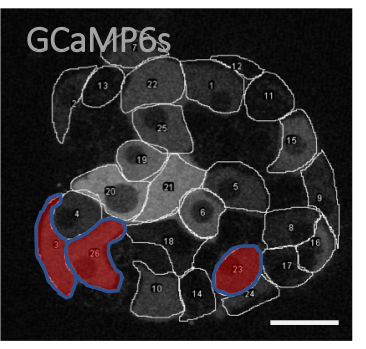

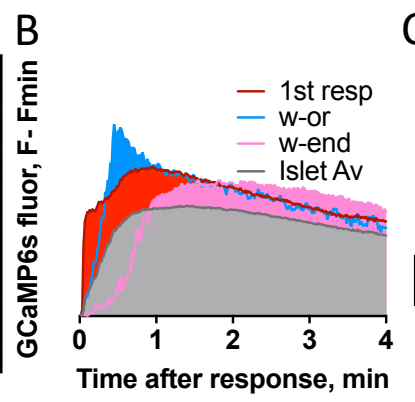
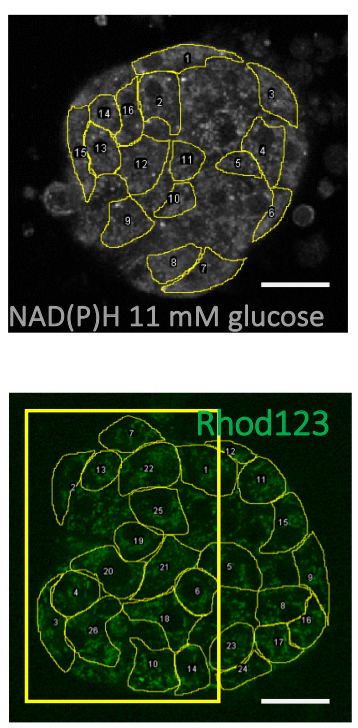

$E$

C
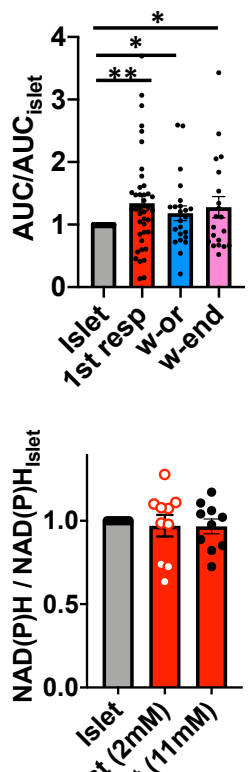

G

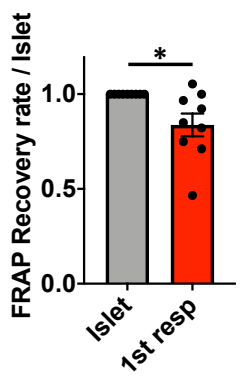

\section{Figure 4}



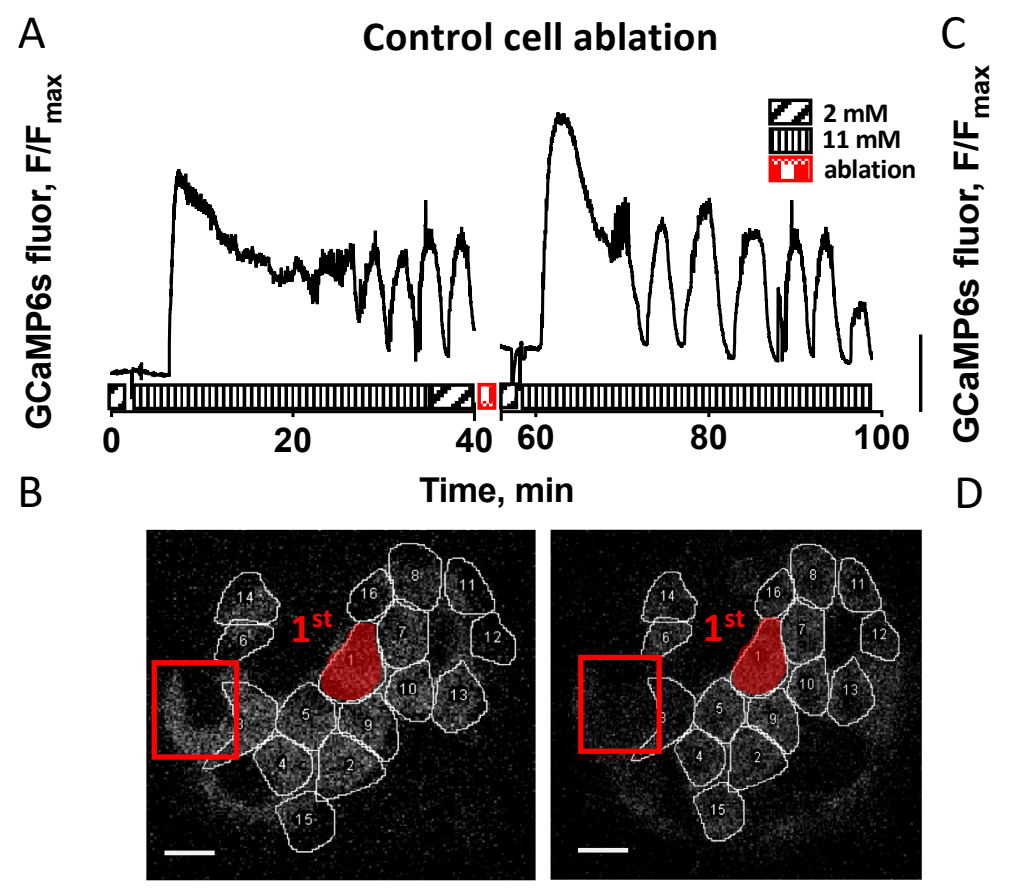

D
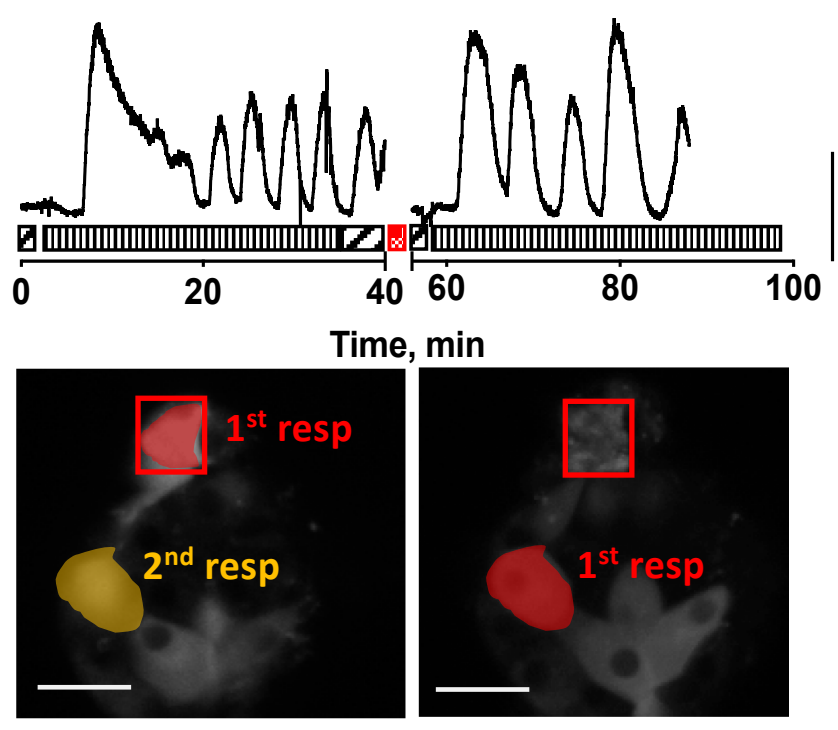

$1^{\text {st }}$ responder cell ablation

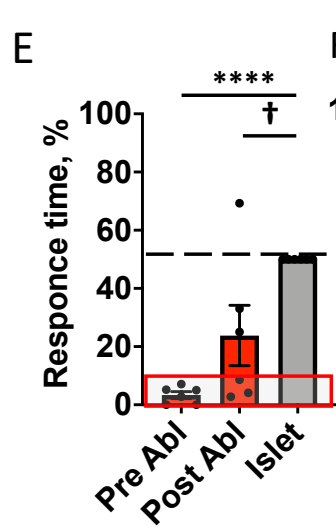

$F$

K
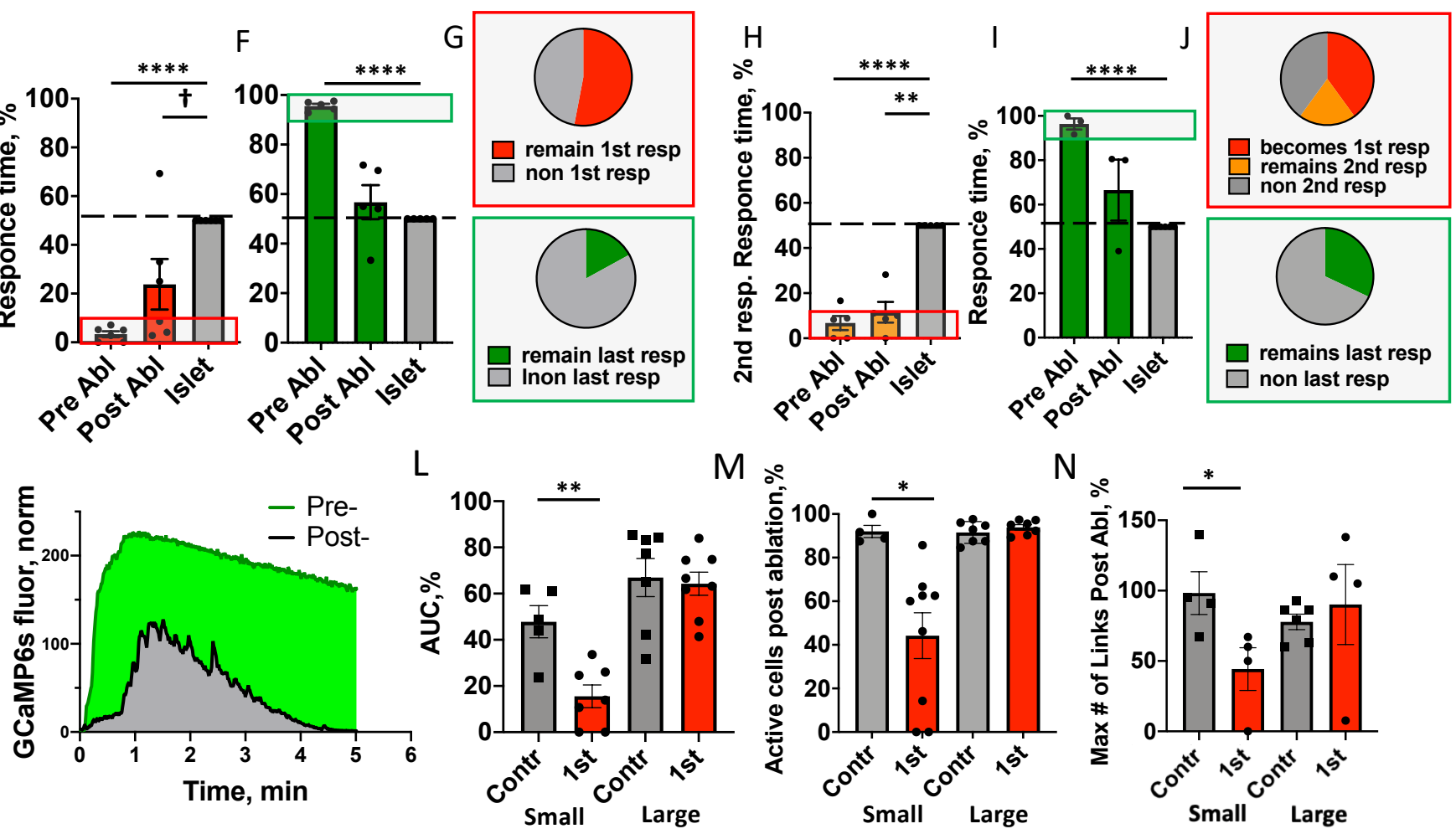

M
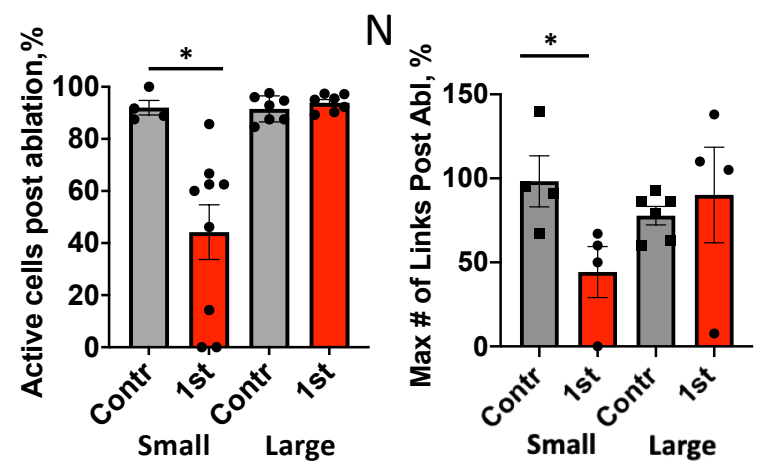

Figure 5 


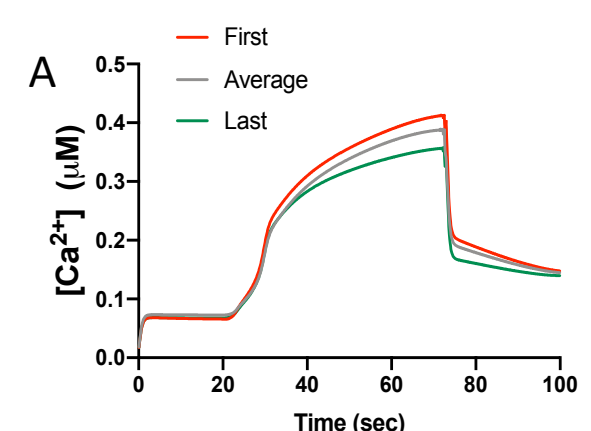

B $2 \mathrm{mM}$

C

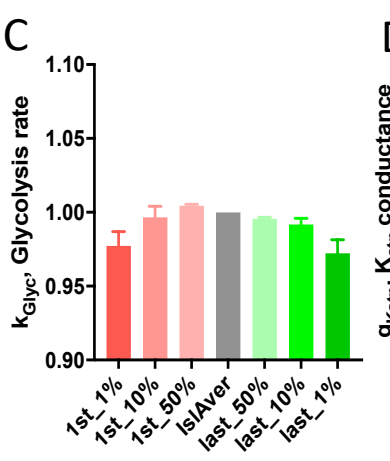

I

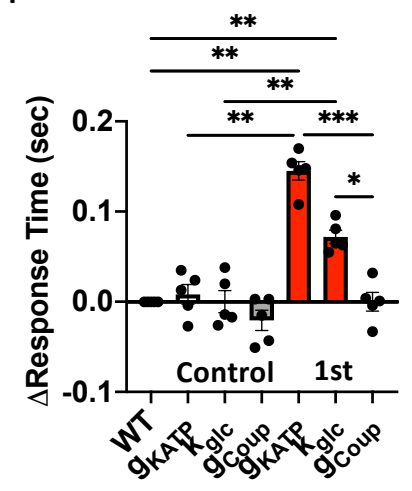

Parameter Adjusted
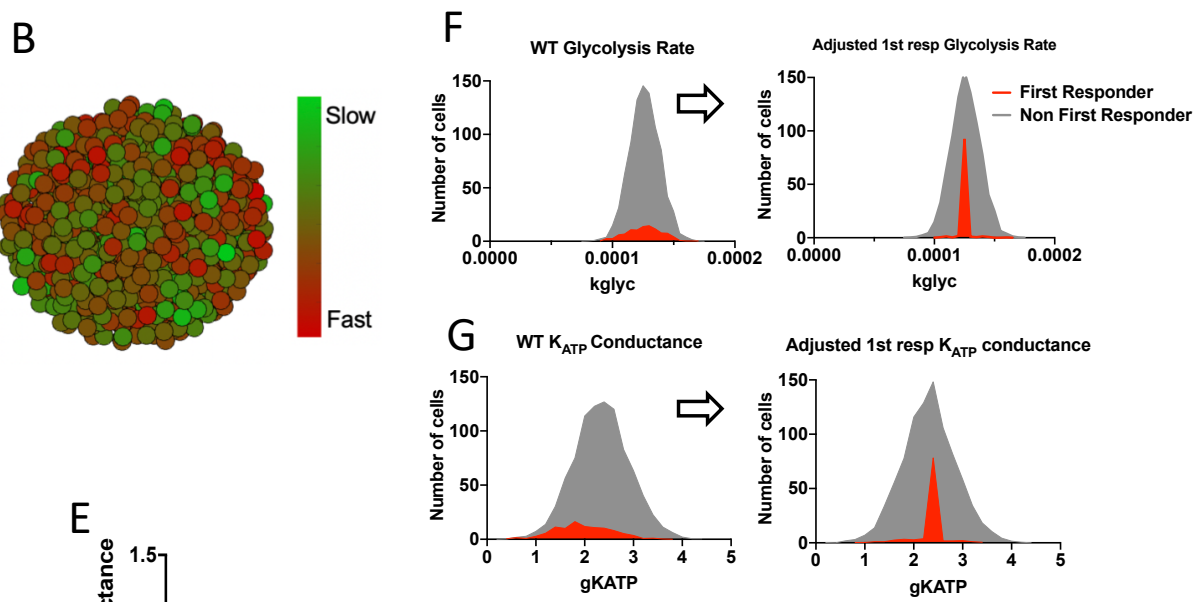

H wT Coupling Conductance
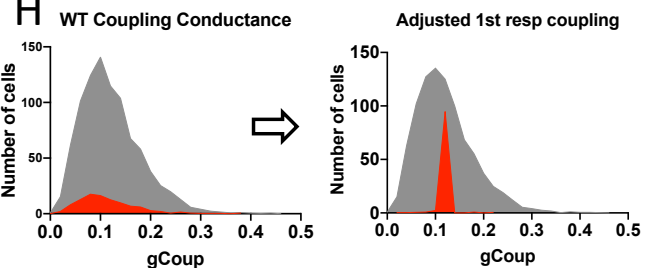

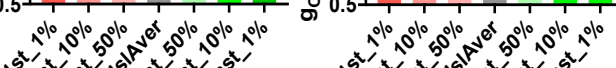

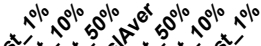

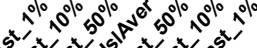

$\mathrm{J}$
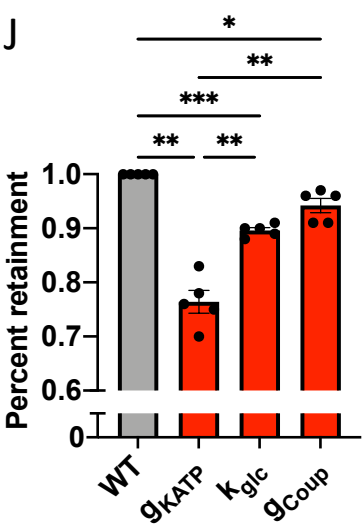

Parameter Adjusted
$\mathrm{K}$

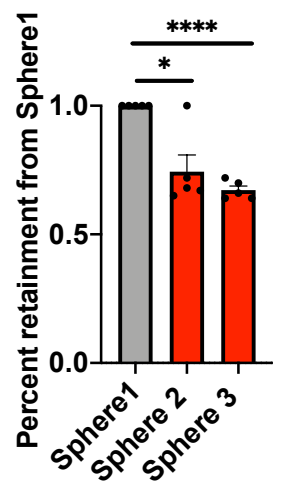

$\mathrm{L}$

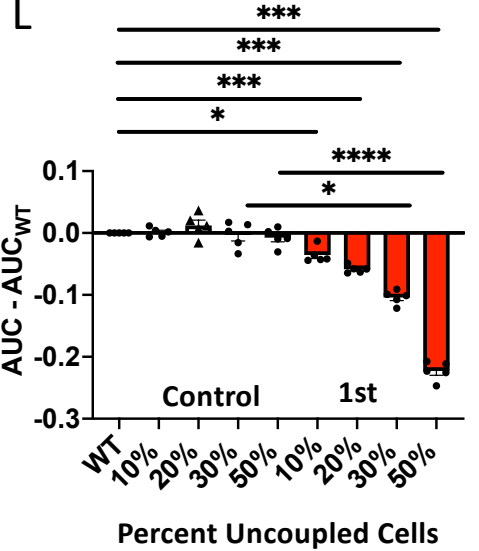

\section{Figure 6}


bioRxiv preprint doi: https://doi.org/10.1101/2020.12.22.424082; this version posted December 24,2020 . The copyright holder for this preprint (which was not certified by peer review) is the author/funder. All rights reserved. No reuse allowed without permission.

A

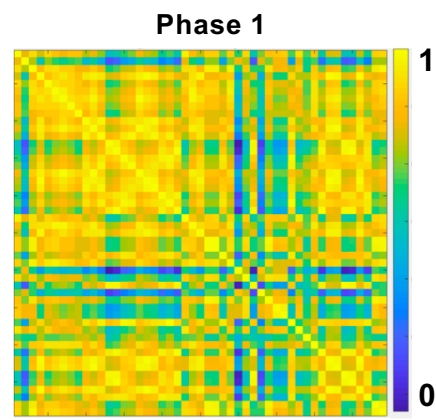

$E$

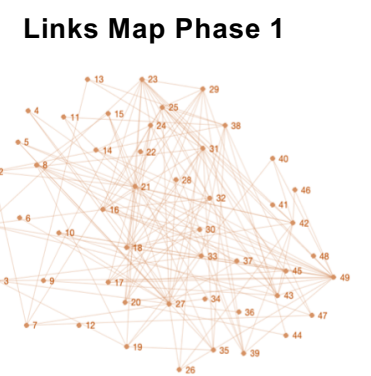

B

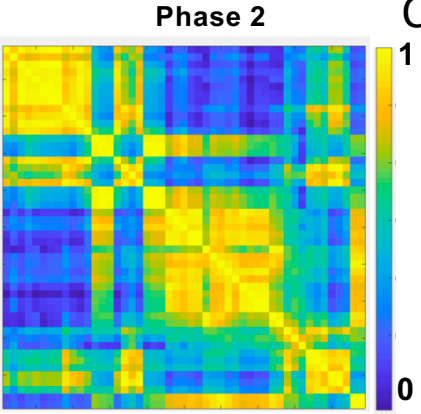

F

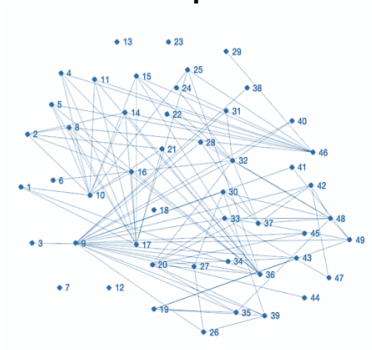

C Adjacency Phase 1
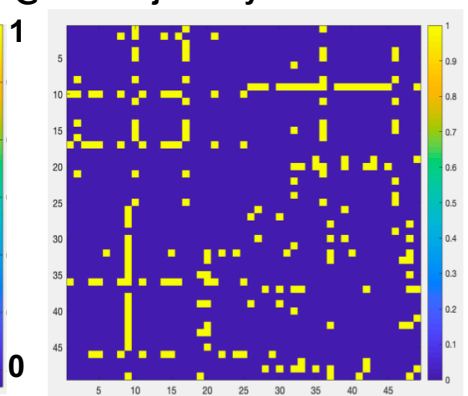

G

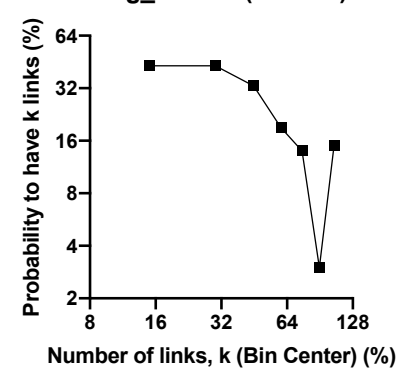

Adjacency Phase 2

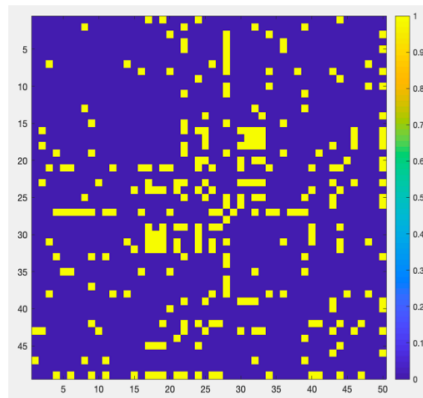

$\mathrm{H}$

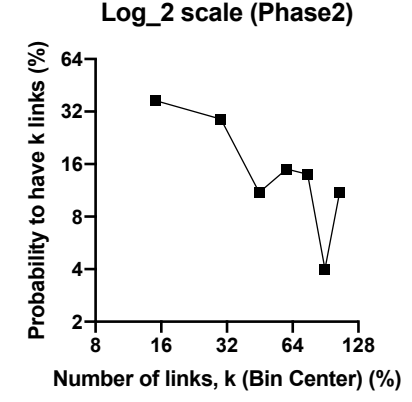

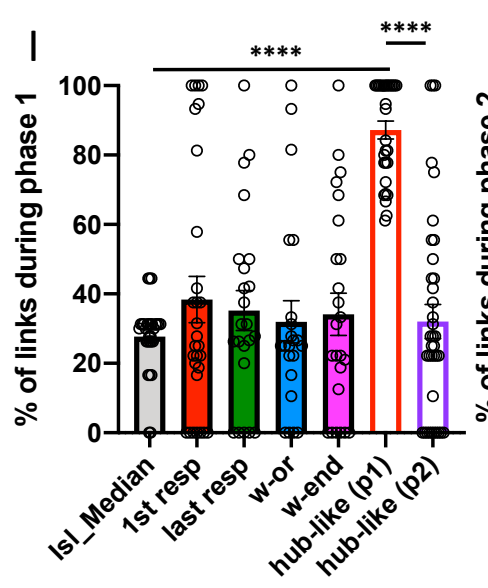
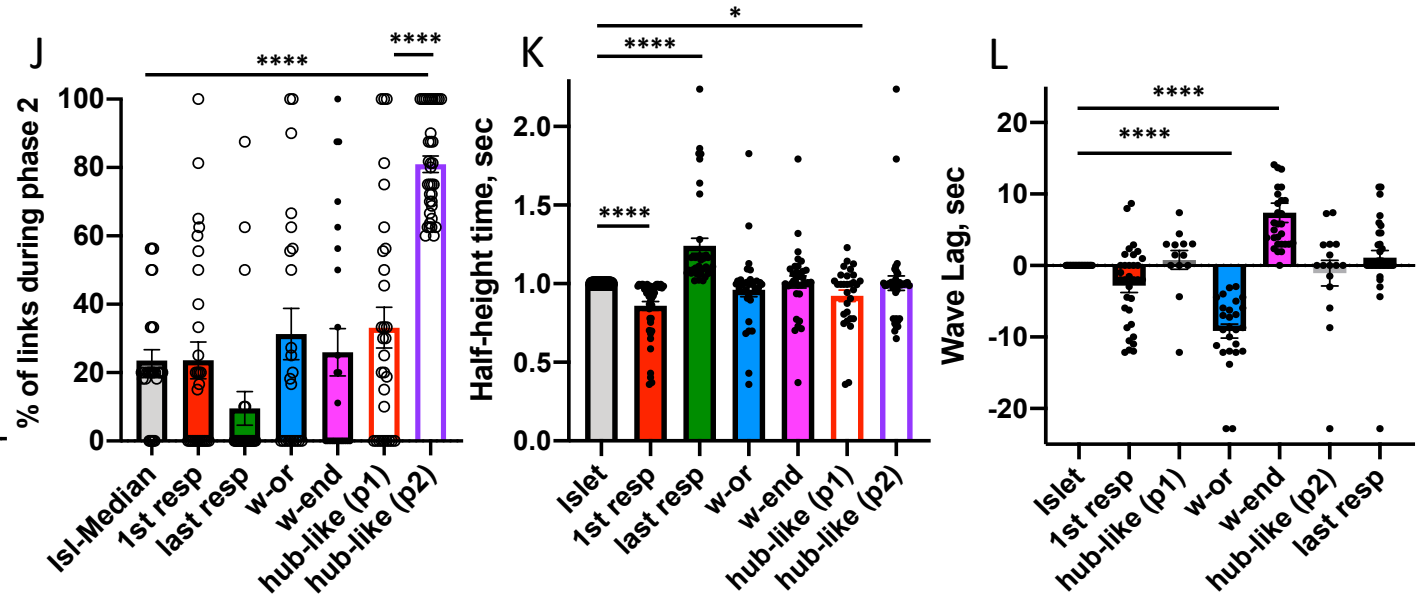

Figure S1 
A

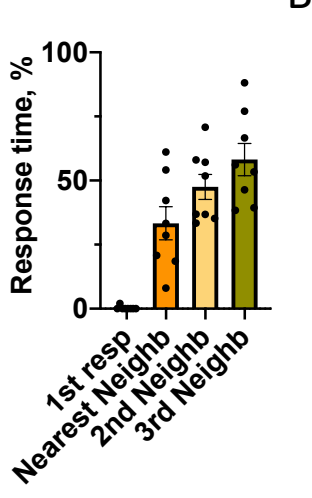

B

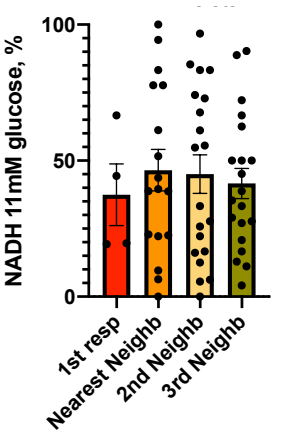

C

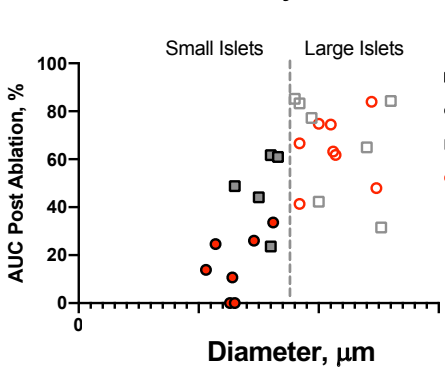

D Islet size distribution

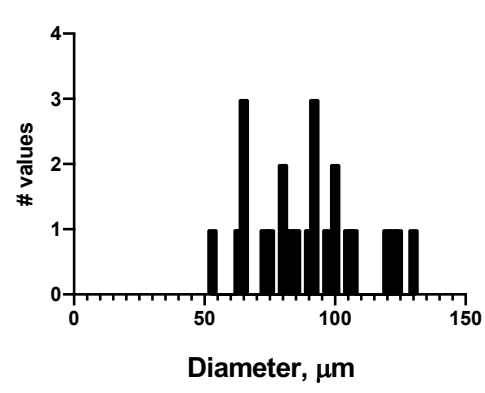

Figure S2 


\begin{tabular}{|c|c|c|c|c|}
\hline Parameter & Description of parameter & Distribution & Mean + Std Dev & units \\
\hline gKATP & $\begin{array}{l}\text { Max conductance of } \mathrm{K}_{\mathrm{ATP}} \\
\text { channel current }\end{array}$ & Normal & $2.31 \pm 0.57$ & $\mathrm{pA} \mathrm{mV} \mathrm{mb}^{-1}$ \\
\hline $\mathrm{kglc}_{\mathrm{glc}}$ & Rate constant of glycolysis & Normal & $0.000126 \pm 0.0000315$ & $\mathrm{~ms}^{-1}$ \\
\hline gCoup & Coupling conductance & Gamma, $\mathrm{k}=\theta=4$ & $120 \pm 30$ & ps \\
\hline $\mathrm{g}_{\text {Кто }}$ & $\begin{array}{l}\text { Conductance of } \mathrm{I}_{\mathrm{KCa}(\mathrm{BK})} \\
\text { (voltage and } \mathrm{Ca}^{2+} \text { ) } \\
\text { dependent transient } \\
\text { outward } \mathrm{K}^{+} \text {current }\end{array}$ & Normal & $2.13 \pm 0.213$ & $\mathrm{pA} \mathrm{mV^{-1 }}$ \\
\hline$P_{\text {SERCA }}$ & $\begin{array}{l}\text { Maximum rate of } \\
\text { pumping } \mathrm{Ca}^{2+} \text { into } \mathrm{ER}\end{array}$ & Normal & $0.096 \pm 0.0096$ & $\begin{array}{l}\text { amole } \\
\mathrm{ms}^{-1}\end{array}$ \\
\hline $\mathrm{P}_{\mathrm{NaCa}}$ & $\begin{array}{l}\text { Maximum amplitude of } \\
\mathrm{I}_{\mathrm{NaCa}} \mathrm{Na}^{+} / \mathrm{Ca}^{2+} \text { exchanger }\end{array}$ & Normal & $204 \pm 20$ & $\mathrm{pA}$ \\
\hline$P_{\text {rel }}$ & $\begin{array}{l}\text { Converting factor for } \mathrm{Ca}^{2+} \\
\text { release from ER }\end{array}$ & Normal & $0.46 \pm 0.46$ & $\mathrm{fl} \mathrm{ms} \mathrm{m}^{-1}$ \\
\hline $\mathrm{P}_{\mathrm{op}}$ & $\begin{array}{l}\text { Maximum rate of ATP } \\
\text { production from oxphos }\end{array}$ & Normal & $0.0005 \pm 0.00005$ & $\mathrm{~ms}^{-1}$ \\
\hline$\left[\mathrm{ATP}_{\text {tot }}\right]$ & $\begin{array}{l}\text { Total amount of ATP } \\
\text { species }\end{array}$ & Normal & $4 \pm 0.4$ & $\mathrm{mM}$ \\
\hline
\end{tabular}

\section{Table S1}

